\title{
Globalization and the Great U-Turn: Income Inequality Trends in 16 OECD Countries ${ }^{1}$
}

\author{
Arthur S. Alderson \\ Indiana University, Bloomington \\ François Nielsen \\ University of North Carolina, Chapel Hill
}

\begin{abstract}
The debate on the resurgence of income inequality in some advanced industrial societies has often focused on the impact of an increasingly integrated world economy, typified by growing capital mobility, heightened international competition, and an increase in migration. This study represents one of the first systematic, cross-national examinations of the role of globalization in the inequality "U-turn." Results indicate, on the one hand, that total inequality variation is principally affected by the percentage of the labor force in agriculture, followed by the institutional factors union density and decommodification, and only then by globalization. On the other hand, longitudinal variation in inequality, while still dominated by the percentage of the labor force in agriculture, is also principally affected by aspects of globalization, such as southern import penetration and direct investment outflow, and to a lesser extent by migration. In other words, globalization explains the longitudinal trend of increasing inequality that took place within many industrial countries better than it does cross-sectional inequality differences among countries.
\end{abstract}

The recent resurgence of income inequality in a number of advanced industrial societies has spawned a wide-ranging debate as to the causes. A recurring theme has been the impact on inequality of an increasingly

\footnotetext{
${ }^{1}$ We thank Howard Aldrich, Ken Bollen, Craig Calhoun, Rachel Rosenfeld, Jason Beckfield, David Brady, and Patricia McManus for their comments on earlier drafts of this article. We also thank Lane Kenworthy and Jelle Visser for providing some of the data. Earlier versions of this article were presented at the spring meeting of the Social Stratification Research Committee ( $\mathrm{RC} 28$ ) of the International Sociological Association in Mannheim, Germany, April 26-28, 2001, the "Re-Inventing Society in a Changing Global Economy" conference in Toronto, March 2001, and the American

(C) 2002 by The University of Chicago. All rights reserved. 0002-9602/2002/10705-0004\$10.00
}

1244 AJS Volume 107 Number 5 (March 2002): 1244-99 
integrated world economy, typified by growing capital mobility, heightened competition in international markets, and a swelling flow of immigrants in some countries. Yet, while a lively debate rages outside the discipline regarding the impact of trade on inequality (e.g., Krugman and Lawrence 1993; OECD 1994; Wood 1994; Burtless 1995; Cline 1997) and the labor market consequences of immigration (Borjas, Freeman, and Katz 1992; Borjas 1994), sociologists have largely been silent on these issues (Morris and Western 1999). Likewise, while there exists a sizeable sociological literature devoted to assessing the effects of direct investment on income distribution in developing societies (e.g., Bornschier, ChaseDunn, and Rubinson 1978; Evans and Timberlake 1980; Bornschier and Chase-Dunn 1985; Firebaugh 1992, 1996; Dixon and Boswell 1996), sociologists have devoted almost no attention to the distributional consequences of international capital flows for advanced industrial societies. In this article, we address these omissions in prior research and examine the link between globalization and the recent inequality experience of OECD countries.

In what follows, we first introduce the inequality data set employed and discuss recent inequality trends in advanced industrial societies. The role of globalization in income inequality is discussed next, and the model of income inequality developed in Nielsen (1994) and elaborated in Nielsen and Alderson (1995, 1997) is introduced to provide a background against which to test hypotheses regarding the distributional consequences of globalization. Finally, we discuss the results of a pooled time-series of cross-sections analysis of income inequality in 16 OECD nations from 1967 to 1992.

\section{RECENT TRENDS IN INCOME INEQUALITY IN THE OECD COUNTRIES}

Two major trends in inequality have marked the experience of the advanced industrial societies in the 20th century: the Kuznets curve and the great U-turn. Kuznets $(1953,1955)$, on the basis of historical data for a handful of industrial societies, conjectured a general developmental pattern in which inequality traces a curvilinear, inverted $U$-shaped relationship with economic development. Thus in the course of long-term industrial development, inequality first increases, peaks and levels off, and then declines. In the case of the United States, for instance, Kuznets found that inequality peaked in the 1890 s, remained stable for a few decades,

Sociological Association annual meeting in San Francisco, August 1998. Direct correspondence to Arthur S. Alderson, Department of Sociology, Indiana University, Ballantine Hall 744, Bloomington, Indiana 47405-6628. E-mail: aralders@indiana.edu 


\section{American Journal of Sociology}

then turned to decline after the 1920s. Subsequent research has generally confirmed Kuznets's findings, both for the United States and for other societies. ${ }^{2}$ While the timing — in terms of calendar time — of the turn away from rising inequality has varied from society to society, the Kuznetsian pattern of rising then falling inequality with development (especially the descending segment) has been shown to typify the experience of an array of industrial societies (Lindert and Williamson 1985; see also Lindert 2000).

The recent experience of some industrial societies suggests a radical reversal of the Kuznetsian scenario of declining inequality with development. Much attention, for instance, has been given to the resurgence of income inequality in the United States, a phenomenon that Harrison and Bluestone (1988) have termed the "great U-turn." After four decades of moderating inequality, income inequality in the United States began to increase around 1970. Since then it has risen at a steady rate, reversing the long-term trend toward declining inequality. A similar upswing in inequality has been observed in some other industrial societies besides the United States, suggesting that the phenomenon has an international character (Green, Coder, and Ryscavage 1992; Freeman and Katz 1995; OECD 1995a; Ram 1997). ${ }^{3}$

One question that arises from these stylized facts regarding the recent inequality experience of the advanced industrial societies is whether the great U-turn is, like arguably the Kuznets curve, an inherent tendency linked to late stages of industrial (or postindustrial) development. Thus

\footnotetext{
${ }^{2}$ For a discussion of the evidence regarding the Kuznets hypothesis, see the review in Nielsen and Alderson (1995).

${ }^{3}$ This article extends our earlier work on income inequality. In Nielsen (1994) and Nielsen and Alderson (1995) we investigate a model of the effects of economic development on income inequality that emphasizes the role of dualism (both economic and "generalized") in generating inequality within the Kuznets curve problematic (as contrasted with the more recent trend of rising inequality associated with the great Uturn that is the object of this article). The first article uses a small cross-national data set; the second uses an unbalanced time series of cross-sections of countries assembled by us, prior to the availability of the Deininger and Squire (1996) income inequality data. In Alderson and Nielsen (1999), we use Deininger and Squire (1996) to construct an unbalanced panel data set for 88 countries to revisit the debate over the role of foreign capital penetration within a dependency theory framework (Firebaugh 1992, 1996; Dixon and Boswell 1996). That article proposes a new model of the impact of capital flows on inequality within core and noncore countries. In Nielsen and Alderson (1997, 2001), we analyze the recent trend of rising inequality in the United States (the great U-turn) using data on 3,141 U.S. counties for 1970, 1980, and 1990. Extending these earlier efforts, the current article (1) focuses on 16 OECD countries, (2) analyzes the factors responsible for recent inequality trends in these countries (including rising inequality in some of them), and (3) is especially concerned with the role of the three major aspects of globalization (capital flows, international trade, and migration) in recent inequality trends.
} 
if one plotted data on income inequality for advanced industrial societies at several points in time over two or three decades against a measure of development, one might expect to see an $\mathrm{N}$-shaped relationship. On the left side of the graph, one would find the least-developed countries at the earlier time points still tracing the up-and-down trajectory of the Kuznets curve (or at least the downward segment of that trajectory). On the right, corresponding to the more developed countries in more recent periods, one might see evidence of an inequality upswing corresponding to the great U-turn. We will show such a plot later (fig. 1).

Unfortunately, cross-national investigation of these two major episodes in the inequality experience of the industrial societies has been hampered by the relative paucity of comparable data on income inequality (Gagliani 1987). Particularly rare are data appropriate to finely drawn comparisons of the level of inequality in, say, the United States and Canada at a given point in time. Recently, this problem has begun to be redressed by the Luxembourg Income Study (LIS) project. Begun in 1983, the LIS project now boasts a database that contains information on 25 (primarily Western industrial) countries for one year or more from the late 1960s to the mid1990s. ${ }^{4}$ Using the raw data from national income surveys, the LIS project reestimates inequality on a standardized basis, adjusting for definitional differences in the aim of maximizing cross-national comparability.

At present, one can assemble a total of 57 observations from the LIS database on the 16 OECD countries that are included in our analysis. Rather than use these data alone, we employ a more inclusive data set in combination with methods of estimation (discussed below) that control statistically for the possibility of systematic differences across countries in inequality measurement. By adopting this strategy, we are able to analyze a cross-national data set that incorporates comparable information on trends in inequality in nearly all of the major industrial countries over the period from the late 1960s to the early 1990s. The data set we employ contains a maximum of 192 observations on 16 OECD countries. It is unbalanced, with countries contributing different numbers of observations according to data availability. The data are drawn from Deininger and Squire's (1996) "high quality" data set, a compendium of inequality data that is generally recognized to contain the best panel data available on income inequality (but see Atkinson and Brandolini 2001). Additional considerations regarding the inequality data are discussed below.

By way of introducing the data set, we present in appendix figure A1 plots of the trends in income inequality for the 16 OECD countries for which we have data. From the inspection of these plots, and ignoring

\footnotetext{
${ }^{4}$ See OECD (1995a) for a succinct overview of the LIS methodology and data set.
} 
American Journal of Sociology

short-term variation, we see the following national patterns emerge over the 1967-92 period:

$\begin{array}{ll}\text { Australia } & \text { rising inequality } \\ \text { Belgium } & \text { declining then rising inequality } \\ \text { Canada } & \text { no clear trend } \\ \text { Denmark } & \text { rising inequality } \\ \text { Finland } & \text { declining inequality } \\ \text { France } & \text { declining inequality } \\ \text { Germany } & \text { declining then rising inequality } \\ \text { Ireland } & \text { declining inequality } \\ \text { Italy } & \text { declining inequality } \\ \text { Japan } & \text { declining then rising inequality } \\ \text { Netherlands } & \text { declining then rising inequality } \\ \text { Norway } & \text { declining then rising inequality } \\ \text { New Zealand } & \text { rising inequality } \\ \text { Sweden } & \text { no clear trend } \\ \text { Great Britain } & \text { declining then rising inequality } \\ \text { United States } & \text { rising inequality }\end{array}$

The cases of Canada and Sweden are exceptionally difficult to summarize. Income inequality in Canada was fairly stable across the 1969-87 period, sharply declined from 1988 to 1989, and rose thereafter. In the case of Sweden, inequality was remarkably stable across the entire 1967-92 period (see also Gustafsson and Johansson 1999). We discern reasonably clear trends in all the other countries under investigation. ${ }^{5}$ If we group together countries that exhibit either the full U-turn pattern (declining then rising inequality) or only the ascending segment of the U-turn (rising inequality), we conclude that 10 out of 16 countries have experienced an inequality upswing during the 1967-92 period. Although the severity of the upswing varies greatly across countries, with Great Britain and the United States experiencing the largest increases, these data suggest that this historical pattern has been common, but not universal, among advanced industrial societies (see also Freeman and Katz 1995).

Figure A1 shows the evolution of inequality as historical trends, plotted against calendar time. As mentioned earlier, one interpretation of these trends may be that the U-turn on inequality is simply the continuation of the Kuznets curve, a pattern inherently associated with late stages of industrial development. To visualize this understanding of the inequality

\footnotetext{
${ }^{5}$ Readers are free to draw their own conclusions from the visual inspection of the plots in fig. A1. The observations we make, however, are generally consistent with those made in the literature on income inequality.
} 
trend, figure 1 shows a plot of inequality against logged gross domestic product per capita (used as a measure of development). The smooth curve is a nonparametric regression line estimated by LOESS, a robust algorithm that is not sensitive to outlying observations (some of which are labeled) (Cleveland 1994, pp. 168-80). The U-shaped relationship anticipated in the above discussion is indeed evident. The general trend that emerges in figure 1 is one of falling then rising inequality with development, albeit with considerable scatter around the main trend. This suggests that OECD countries collectively conform to the overall U-shaped inequality trajectory implied by the two major trends discussed earlier; at lower levels of development, one can observe the tail end of the longterm decline in inequality associated with the Kuznets curve, while at higher levels of development (corresponding by and large to more recent time points), one observes the upswing in inequality associated with the great U-turn. Labeled points show that the declining segment of the curve on the left of the graph corresponds to early observations on Ireland and Japan, while the inequality upswing on the right, driven in part by late observations for the United States, is pulled down by several observations for Canada, which feature low inequality at high GDP levels. Excluding observations for Ireland and Japan does eliminate the declining segment of the curve, but removing observations for the United States and Canada only clips the right-most third of the upturn, without eliminating it. The United Kingdom, even though it has experienced a major U-turn on inequality, does not contribute much to the upward trend in the figure because of the relatively low GDP levels of the corresponding observations. The existential status of the great U-turn as a function of development thus appears similar to that of the Kuznets curve: it is there (in the data), but it is easy to miss because of the considerable scatter around the main trend. ${ }^{6}$

\section{GLOBALIZATION AND THE U-TURN ON INEQUALITY}

The recent upswing in inequality in some OECD countries has been attributed to diverse causes. Much interest has focused on the question of the role of globalization in this phenomenon (e.g., Väyrynen 1997). In

\footnotetext{
${ }^{6}$ Fig. 1 is based on the 187 observations used in the analysis (i.e., multivariate outliers have been removed). To what extent is the U-shaped relationship observed in fig. 1 driven by the countries with the largest number of observations? If the United States (25 observations), United Kingdom (24 observations), Canada (19 observations), and Japan (19 observations) are excluded, the U-shaped relationship is still apparent. Indeed, a quadratic function of development fits the data nearly as well with these cases excluded $-R^{2}=.100$ vs. .109 (see model 1 in table 2 ).
} 
American Journal of Sociology

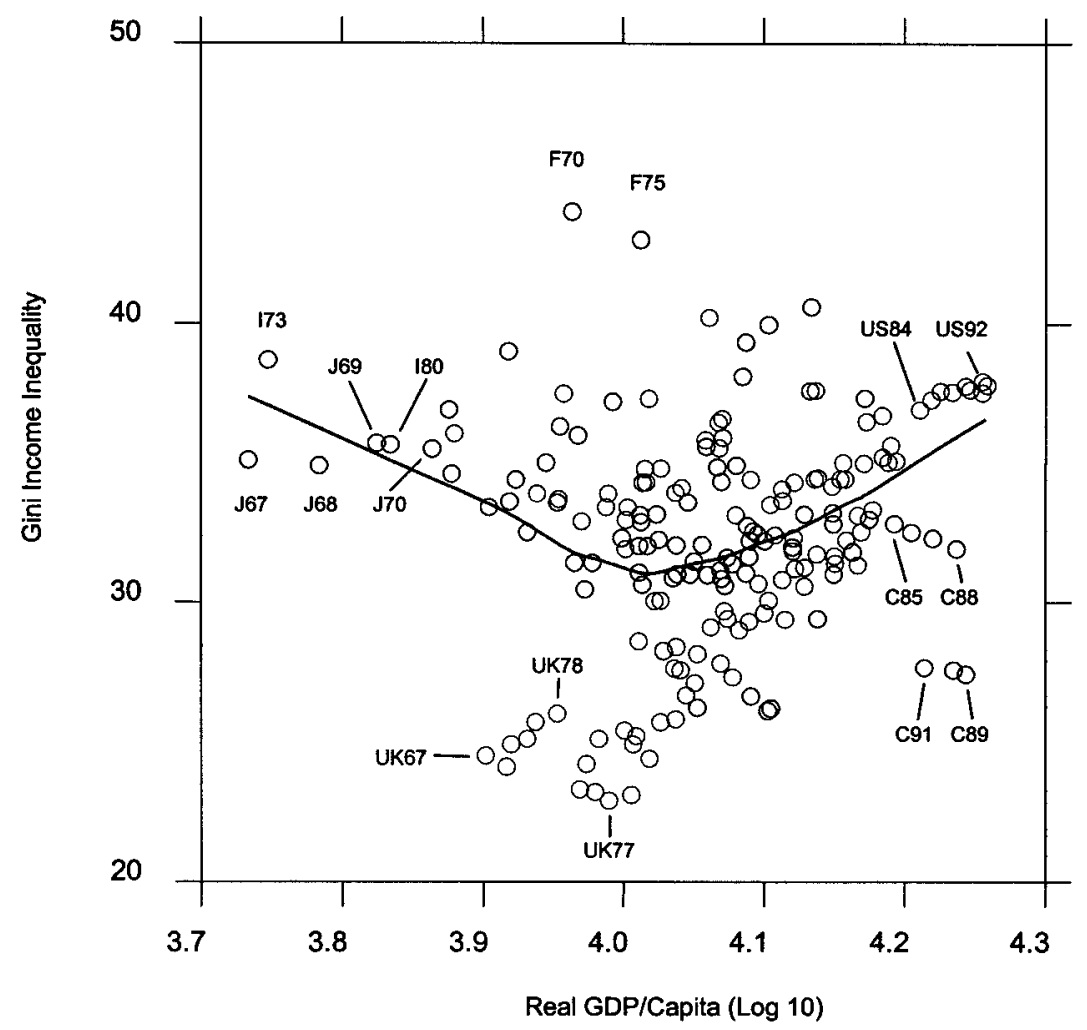

FIG. 1.-Scatterplot and nonparametric regression line showing the relationship of the Gini coefficient of income inequality to real GDP/capita (log base 10): 187 observations from 16 OECD countries, 1967-92. Observations labeled are those for Ireland (I), Japan (J), France (F), Canada (C), the United States (US), and the United Kingdom (UK).

making this link, researchers have focused on the impact of three distinct aspects of globalization. Two of these aspects are rising foreign direct investment and "North-South trade" (i.e., trade between developed and developing societies). Both have become increasingly prominent features of the advanced industrial societies in recent years (Alderson 1997). Between 1982 and 1990, for instance, the value of outflows of direct investment from the OECD countries grew from 20 billion U.S. dollars to over 228 billion (IMF 1987, 1994). The value of OECD manufactured imports from "Southern" countries (i.e., non-OECD, non-COMECON) grew from around 87 billion U.S. dollars to 298 billion (OECD 1984, 1992). A third aspect of globalization implicated in recent inequality trends is migration. According to the United Nations (1989, p. 61), the percentage of the population foreign born is $6 \%$ in Austria, nearly $9 \%$ in the United 
States, $11 \%$ in France, and $17 \%$ in both Canada and Switzerland (cited by Borjas 2000, p. 1). We discuss these three aspects of globalization in turn.

Direct Investment and Inequality

One part of the "globalization thesis" on the inequality upswing focuses on the distributional consequences of the direct investment activity of multinational enterprises (hereafter MNEs). We discern three (complementary) strains of thinking in the literature: (1) one that stresses the role of direct investment in deindustrialization, (2) one that focuses on the bargaining position of labor under conditions of globalization, and (3) one that highlights the "cheapening" of labor (particularly low-skill labor) that can result as jobs are "exported" through international relocation.

The first school of thought suggests that "capital flight" or the outflow of direct investment (hereafter DI) from the advanced industrial countries has generated higher levels of inequality by accelerating deindustrialization, a factor whose effect on income distribution is well established in the empirical literature. ${ }^{7}$ The work of Bluestone and Harrison (1982; see also Harrison and Bluestone 1988) is representative of this approach. Harrison and Bluestone argue that DI in the contemporary period is being undertaken as part of a "globalization gambit." This move is argued to constitute an integral part of a new set of corporate strategies designed to abrogate the old postwar social contract between capital, labor, and the state and, in doing so, to restore acceptable levels of profitability in response to the "profit squeeze" of the 1970s. The result of this strategy, they argue, is a kind of hollowing of the economy of the capital exporting country. By hollowing, they mean that firms are no longer undertaking DI in an effort to complement domestic investment and production, but to replace it. Thus in recent years, as firm after firm in the manufacturing sector has decided to invest abroad in search of lower labor costs, the end result has been deindustrialization. Deindustrialization has, in turn, produced rising inequality because it has entailed the movement of a portion of the labor force from the industrial sector, typified internally by higher average wages and a comparatively flat distribution of income, to the service sector, typified internally by lower average wages and a higher level of inequality. Moreover, the decline of employment in the industrial

\footnotetext{
${ }^{7}$ We will not go into great detail here discussing the connection between deindustrialization and the growth of inequality. For supporting evidence, see Harrison and Bluestone (1988); Green, Ryscavage, and Welniak (1991); Lorence and Nelson (1993); Preston and McLafferty (1993); and Nielsen and Alderson (1997). For dissenting voices, see Levy (1987) and Raffalovich (1993).
} 
American Journal of Sociology

sector is seen as further contributing to the growth of inequality by undermining the power of unions and their ability to maintain traditionally high industrial wages.

A second, related line of thinking focuses on the effects of direct investment on the bargaining position of labor. The basic argument is that labor may be inherently weaker vis-à-vis multinational firms than it is in relation to national firms (Alderson 1997). There are a number of reasons why this might be the case. First, "multinationality" results in the dispersion and fragmentation of labor. This makes it more difficult for labor to organize itself (Ietto-Gillies 1992, p. 138). While union links tend to be strong, nationally, within the same company (even when plants are spread over many sites), the international harmonization of the demands of the employees of MNEs is exceedingly rare. Thus the ability of a firm to check labor's bargaining power and thus lower the costs associated with it may be enhanced by the simple act of opening additional foreign operations (see Scott and Storper [1986] and Cowling and Sugden [1987] for early versions of this argument). Second, multinationality allows firms to erase the spatial (and other) barriers that work to insulate domestic labor from foreign competition and the political interventions that influence the functioning of national labor markets. In essence, the firm is able, through internationalization, to induce competition in its home labor market by effectively increasing labor supply, as segments of the now culturally and politically fragmented workforce are brought into competition with each other for employment within the firm (Huizinga 1990). Finally, multinationality may particularly strengthen the firm's hand in relation to the host nation's workforce. The MNE, as a new entrant, is to an important extent free to set its own terms, unhindered by the historical and cultural "baggage" of prevailing industrial relations practices. As a result, MNEs are likely to enjoy greater managerial control and labor flexibility than comparable domestic firms, features that may translate into a distinct productivity and cost advantage (Enderwick 1985; Buckley and Enderwick 1985). Viewed together, these arguments suggest that globalization may have important distributional consequences over and above other considerations; inasmuch as the direct investment activity of MNEs weakens labor's bargaining position and exerts a downward pressure on the wages of (typically) organized, middle-income workers, it contributes to the phenomenon of the "declining middle" and to polarization in the distribution of income.

A final strain of thinking on the role of direct investment in the inequality upswing suggests that DI may directly affect income distribution by altering (1) the distribution of income between capital and labor and (2) the demand for low-skilled labor. To the degree to which DI outflow from advanced industrial countries represents a real loss of productive 
capacity, it will cheapen labor. This happens because, as workers in the home nation are assisted by less capital in the production process, the marginal product of labor will fall and the marginal product of capital will rise. This will result in a rising share of national income going to capital. Under such conditions, one would expect to observe growing inequality in the distribution of income. In addition, if DI outflow is primarily skewed toward low-skill processes, if, as some observers have argued, "low-skill jobs are in effect being 'exported' to low-wage countries through relocation" (Lee 1996, p. 487), then DI will reduce the demand for low-skill labor. This fall in the demand for low-skill labor will, in turn, cause a fall in the earnings of low-skill workers relative to the more skilled, thereby contributing to rising inequality.

These latter arguments regarding the direct effects of DI on income distribution depend sensitively on two assumptions. First, and most obviously, for DI to affect income distribution in this fashion, it must represent a displacement of investment that otherwise would have taken place in the home country (Lee 1996). This point is highly controversial, with some scholars tending to view DI as a substitute for domestic investment (Ietto-Gillies 1992) and others viewing it as merely adding to other forms of investment (Hufbauer and Adler 1976; Bhagwati 1994). Second, such arguments assume little (or no) adjustment though trade, a process that might check the "cheapening" of domestic labor that results from DI (Caves 1982; Enderwick 1985). ${ }^{8}$ Nonetheless, when combined with the arguments that have emerged from the literature on deindustrialization and bargaining under conditions of globalization, a rough framework does emerge for the interpretation of observed effects of DI on income distribution. Each strain of thinking argues a positive relationship between DI outflow and income inequality. Over the short run, DI outflow may generate inequality in the home country because it prompts deindustrialization and weakens the bargaining position of labor.

${ }^{8}$ Take the example of an industrial nation that exports capital-intensive goods and imports labor-intensive goods. Assume DI abroad by that nation's export-oriented firms. The "cheapening" of labor that results would favor that nation's importcompeting (more labor-intensive) industries and induce a shift in capital investment toward those industries. As Caves notes, this shift "mitigates the negative effect of capital's emigration on the wage of Home's labor. That is because in neither Home's exporting industry nor its import-competing industry is the decline in the capital-labor ratio as large as it is for the country as a whole. That seeming impossibility results because the transfer of factors from Home's export-competing industry releases a lot of capital, and only a little labor, relative to the proportions called for in Home's import-competing industry. The interindustry shift of factors of production thereby does part of the job of adjusting to the economy's overall lower capital-labor ratio. Because the capital-labor ratio in each sector falls less, the wage falls less than it otherwise would" (Caves 1982, p. 133; emphasis in original). 


\section{American Journal of Sociology}

Over the longer run, DI outflow may generate inequality in the home country because it will cheapen domestic labor, redistribute income from labor to capital, and reduce the demand for low-skill labor.

\section{North-South Trade and Inequality}

The search for culprits in the inequality upswing has also focused closely on the role of international trade, particularly North-South trade (see review in Cline 1997). Arguments linking trade to recent changes in income distribution in the developed countries take two basic forms (Messerlin 1995).

The first version of the argument is that North-South trade affects overall inequality by reducing the average wage in the North. NorthSouth trade is held to reduce the average wage because (1) it brings northern workers into direct competition with southern workers and (2) the intensified competition that this induces spreads across the labor market, affecting skilled workers as well. This version of the argument can be shown, in many cases at least, to be a fairly weak one. If one examines the ratio of the average wage in the OECD countries to the (import weighted) average wage of their trading partners, one will find, for a number of countries, a value close to one, meaning that half or more of trade is with comparatively high-wage partners (i.e., other OECD countries; Krugman and Lawrence 1993). In such cases, the net effect of imports on the average wage will be minimal.

The second version of the argument linking trade to the upswing in inequality in the advanced industrial countries stresses the effects of trade on the relative wages of the skilled and unskilled. Here North-South trade generates inequality because, by reducing the demand for unskilled labor in the North, it increases the disparity in returns to unskilled relative to skilled labor. This second version is arguably more robust prima facie. Nonetheless, the contribution of this mechanism to overall inequality has tended to be discounted, with most studies indicating that the impact of North-South trade on northern labor markets is minimal. ${ }^{9}$

Recently, however, Wood (1994) has breathed new life into this debate. Bringing a variety of forms of evidence to bear on the question, Wood marshals a persuasive case in favor of the view that the upswing in NorthSouth trade has had a significant effect on the demand for skilled relative

\footnotetext{
${ }^{9}$ See, e.g., the much discussed $O E C D$ Jobs Study (1994). Upon reviewing the available evidence, the authors conclude that "the ... analyses . . . largely confirm the findings of others in the field, namely that the impact of changing trade patterns on labour market conditions is significant, but generally small relative to other factors" (p. 105). See also the conclusions drawn in the ILO's World Employment 1996/97 (1996).
} 
to unskilled labor. Wood's argument proceeds in three steps. First, he uses a variety of indicators to show that income differentials by skill level have indeed widened in the North, particularly since around 1980. The evidence reviewed regarding changes in the returns to education, in the average wages of white-collar relative to blue-collar workers, and in general wage dispersion in the OECD countries is consistent with widening skill differentials. Second, he establishes that widening income differentials by skill level resulted from trade-induced shifts in demand for skilled and unskilled labor. Prior literature, evidence regarding the timing and magnitude of the upswings in North-South trade and in skill differentials, and patterns of cross-national variation and variation in the demand for male and female labor are all shown to be highly consistent with this interpretation. Finally, he addresses an array of alternative explanations for widening skill differentials. Among these, he finds greatest merit in the argument that autonomous technological changes (centering around the microprocessor) have had an unskilled labor-saving bias, but he views the evidence as suggesting a larger role for trade.

All told, Wood makes a strong case for the idea that the upswing in southern imports has had a significant impact on the demand for skilled relative to unskilled labor. As the demand for skilled labor has increased relative to unskilled labor, the returns to each should diverge. As regards overall inequality, Wood suggests that "it seems quite likely that the widening of skill differentials . . was the main cause of . . changes in the trend of household income distribution" (1994, p. 254). This argument lends itself to the straightforward prediction that southern import penetration will have a positive effect on income inequality. This conclusion, however, is subject to an important caveat:

A complication in the North . . . is that wider wage differentials tend to be resisted, especially in [continental] Europe. The resistance arises partly from the power and egalitarianism of labor unions, partly from minimum wage legislation, and partly from minimum income provisions in social security systems (which make people unwilling to accept low-wage jobs). In so far as these institutional forces reduce relative wage flexibility, the pressure for wider skill differentials emerges in a different form-as shortages of skilled labor and surpluses of unskilled labor [and thus unemployment]. (Wood 1994, p. 15)

Greater inequality and unemployment may thus be trade-offs in the contemporary period. Where institutional resistance to wider wage differentials is weak, southern import penetration may produce widening wage differentials and greater overall income inequality. Where such resistance is strong, however, it may express itself in rising unemployment. This suggests that factors that contribute to the level of resistance to inequality, 


\section{American Journal of Sociology}

such as the strength of workers unions and the extent to which wagesetting decisions are centralized, will buffer the effect of southern import penetration on income inequality. We will therefore investigate the role of these institutional factors below.

Migration and Inequality

A third aspect of globalization has been an increased movement of people across national borders, that is, migration. In the United States, migration has come under serious suspicion as a factor in the inequality upswing for three main reasons: (1) the rate of immigration has increased coinciding roughly with the period of increasing inequality, (2) "there has been a precipitous decline in the average skills of the immigrant flow reaching the United States, relative to natives" (Borjas 2000, p. 4), and (3) "the immigrant population is highly bifurcated; there are many immigrants with few skills and many immigrants who are highly skilled" (Borjas 2000 , p. 5). The combination of a high immigration rate with an immigrant population characterized by low average skills and high skills variance has been seen as a certain recipe for increased inequality. Borjas and colleagues have estimated that almost half of the decline in the relative wage of school dropouts that took place between 1980 and 1995 can be attributed to immigration (Borjas, Freeman, and Katz 1992; Borjas 1994, 2000).

While the high-end estimate of the impact of immigration on inequality in the United States obtained by Borjas and his colleagues is not universally accepted, and the immigration situation of the United States may not be typical of that of other OECD countries, there are historical precedents that motivate paying close attention to immigration as a possible general factor in the inequality upswing. Hatton and Williamson (1998) point out the remarkable similarities between the international situation in the period from about 1870 to 1913, and the second half of the 20th century. Both historical periods were characterized by expanding international trade, convergence between poor and rich nations, and large population movements leading to inequality outcomes that differed by type of country: in the relatively rich, people-importing nations of the time, including Argentina, Australia, Canada, and the United States, immigration caused inequality to increase; in the poor, people-exporting nations, which included at that time both Southern European (Italy, Spain, Portugal) and Scandinavian countries (Norway, Sweden, Denmark), emigration produced a decline in inequality. Thus, when we observe an inequality upswing in some of the rich, people-importing countries in recent decades, it is not unreasonable to suppose that immigration may be a contributing factor. 
Income Inequality Trends

\section{THE USUAL SUSPECTS: ALTERNATIVE MODELS OF INCOME INEQUALITY}

In the regression models of income inequality analyzed below, we will include measures of the three aspects of globalization (DI outflow, NorthSouth trade, and migration) to estimate their separate contributions to inequality. We will test the globalization variables in models incorporating alternative mechanisms of inequality that have been identified in two relatively independent traditions of research. One research tradition has focused on the problematic associated with the inverted U-shaped pattern taken by income inequality in the course of development first identified by Kuznets (1955), usually in a broad cross-national comparative framework. The second tradition has focused on the mechanisms of the more recent U-turn on inequality, often focusing on the special case of the United States. These two traditions of research have proceeded along independent paths, with each tradition evoking a distinct set of explanatory factors. In what follows, we address the hypotheses that emerge from these literatures in turn. Our goal will be to construct a combined model that sheds light on the general question of the mechanisms driving the U-turn on inequality, thereby contributing to a burgeoning cross-national comparative literature on the inequality upswing (Freeman and Katz 1995; Gottschalk, Gustafsson, and Palmer 1997; Gottschalk and Smeeding 1997; Gustafsson and Johansson 1999).

Inequality and Development: The Kuznets Problematic and the Core Model

The Kuznets hypothesis suggests that for societies at relatively high levels of development there is a negative relationship between inequality and development, as these societies are presumably arrayed along the rightmost segment of the inverted U-shaped curve tracing the relationship of inequality with economic development. To the extent that the Kuznetsian pattern continues to typify the experience of the advanced industrial societies, we expect to observe a negative relationship between the Gini coefficient of income inequality among households and the level of development measured as real GDP/capita. To the extent, however, that the more developed societies in more recent periods are arrayed along an ascending slope of inequality and development (fig. 1), a development quadratic will better fit the data.

To account for the Kuznets hypothesis, we use the "core" model of inequality and development devised in Nielsen (1994; see also Nielsen and Alderson 1995, 1997; Alderson and Nielsen 1999) that incorporates three major features of development: labor force shifts and sector dualism, 


\section{American Journal of Sociology}

the demographic transition and generalized dualism, and skills deepening and the spread of education. These are represented by four variables in the regression analysis. The rationale for the inclusion of each is discussed briefly below. The general specification of the core inequality model is as follows:

$$
g=f(\text { sdu, lfa, nri, sec }),
$$

where $g$ is gini income inequality, sdu is sector dualism, lfa is \%labor force in agriculture, nri is natural rate of population increase, and sec is secondary school enrollment ratio.

Kuznets's (1955) explanation of the peculiar shape of the relationship he observed between inequality and development stressed the dualism that emerges between the agricultural and nonagricultural sectors of a developing society. Schematically, a society at an early stage of development is characterized by the coexistence of a small modern sector, typified internally by high productivity and wages, and a large traditional agricultural sector, typified by low productivity and wages. With development, an increasing proportion of the labor force shifts from the lowincome agricultural sector to the high-income modern sector. As this shift takes place, inequality will, solely on the basis of these average differences between sectors, increase, peak, then decrease. Thus as a mechanical consequence of the movement of the labor force out of agriculture, inequality will conform to an inverted U-shaped trajectory (see fig. 2 in Nielsen [1994] for an illustration of this phenomenon).

This inequality, attributable to differences in average income between sectors, is called sector dualism. Sector dualism is a function of the difference in average income between sectors and the relative size of the sectors. The countries under investigation exhibit relatively low (and declining) levels of sector dualism, primarily because agricultural employment is relatively low as a proportion of total employment but also because productivity (and wage) differentials across sectors in such societies are comparatively minimal. However, given that a majority of the OECD countries had yet to complete the transition out of agriculture by the beginning of the period under investigation, sector dualism may nonetheless remain a significant predictor of inequality. ${ }^{10} \mathrm{We}$ will test the prediction that sector dualism will have a positive effect on overall inequality among households.

Sector dualism measures the contribution to overall inequality of differences in average income between sectors. The distribution of the labor

\footnotetext{
${ }^{10}$ As late as 1967, the employment share of agriculture was over $10 \%$ in Austria, Denmark, France, Germany, Norway, and Sweden and over 20\% in Finland, Ireland, Italy, and Japan.
} 
force across sectors can also affect overall inequality to the extent that inequality differs within sectors. Kuznets (1955) proposed that inequality is typically lowest in the agricultural sector, which he characterized as being composed of economic units of roughly similar size. The larger the agricultural sector, then, the greater the weight given to the more equal sector. We will control for the size of the agricultural sector and expect that, net of sector dualism, the \%labor force in agriculture will have a negative effect on income inequality. If this prediction is not supported in the context of OECD countries, it may mean either that Kuznets's assumption was never valid, or that it was once true but is no longer.

The demographic transition is another major feature of development that has been implicated as a cause of the inverted-U shape of the Kuznets curve. Two general mechanisms have been identified through which the demographic transition may affect inequality. The first focuses on shifts in the age distribution of the labor force that occur as the rate of population growth rises and then declines over the course of the demographic transition. Countries in the early stages of the demographic transition will exhibit a large and growing cohort of younger workers. This means that such countries will have a similarly large and growing proportion of workers at the bottom of the earnings scale. This influx of younger (unskilled) workers into the labor market can also be expected to contribute to a surplus of unskilled labor, further widening the wage differential between the skilled and unskilled (Kuznets 1955; Lindert and Williamson 1985; Williamson 1991). Thus one would expect to observe a positive relationship between the rate of population growth and income inequality. In addition to this purely demographic mechanism, the model discussed in Nielsen (1994) suggests that the demographic transition may affect inequality because it proxies for generalized sociocultural dualism, the general social heterogeneity resulting from the uneven diffusion of modern technology and culture in the course of development. Akin to the main process of sector dualism discussed above, any item or trait associated with development that has implications for income and that is distributed unevenly over the population will generate its own sectoral inequality. To the extent that these mechanisms are still at work in the OECD countries in the period under study, we expect that the natural rate of population increase will have a positive effect on income inequality.

Another major aspect of development is the diffusion of education or "skills deepening." Looking across a broad cross-section of countries, the usual expectation is that the spread of education will have a negative effect on overall inequality, consistent with straightforward supply and demand reasoning under which an increase in the supply of skilled (or credentialed) workers will reduce the wage differential between the skilled and unskilled (Lecaillon et al. 1984). A few researchers have pointed out, 


\section{American Journal of Sociology}

however, that the relationship between income inequality and the diffusion of education may differ among the advanced industrial societies. Crenshaw and Ameen (1994) argue that in fact the relationship is reversed and becomes positive at high levels of educational expansion, reflecting the emergence of a new postindustrial regime. Jacobs (1985) suggests that the distribution of educational attainment affects the distribution of income through the dispersion of education rather than through the average level. Data limitations mean that we are unable to test the compositional hypothesis suggested by Jacobs. ${ }^{11}$ We can, however, explore Crenshaw and Ameen's conjecture regarding the shape of the relationship between inequality and educational diffusion. There is substantial variation in rates of enrollment in secondary schools among OECD countries. We will test the hypothesis that the diffusion of education, measured as the secondary school enrollment ratio, has a negative effect on income inequality and will also search for the curvilinearity posited by Crenshaw and Ameen.

The four variables just discussed constitute the core regression model of inequality. It was originally developed to explain the inverted $U$-shaped trajectory of inequality with development that can be observed in crosssections of countries that vary substantially in development levels. The model is able to capture the curvilinear pattern of the Kuznets curve, without using any polynomial function, because it contains two variables that themselves tend to follow an inverted $U$-shaped trend in the course of development: the rate of natural population increase (because of the demographic transition) and sector dualism (because of the dualism effect explicated by Kuznets [1955]; Nielsen 1994). As the data set used in this article consists of advanced industrial societies, the model is not expected to exhibit the full curvature of the Kuznets pattern. Rather, coefficient estimates should be consistent with a monotonous pattern of declining inequality with development characteristic of later phases (the right-hand side) of the curve. In the next section, we turn to discuss those factors (in addition to globalization) that might account for a reversal of the trend toward declining inequality with development.

\section{The Great U-Turn Problematic}

In subsequent work, we expanded this earlier core inequality model to incorporate explanations that have been proposed for the recent upswing

\footnotetext{
${ }^{11}$ In a study of income inequality in U.S. counties, we constructed a measure of $e d$ ucational heterogeneity to test the compositional hypothesis. The results indicated that educational heterogeneity has had a strong positive effect on county-level inequality (Nielsen and Alderson 1997). Unfortunately, the sort of educational attainment data necessary for the construction of a comparable (and reasonably complete) measure of the dispersion of education for other OECD countries is simply unavailable at present.
} 
in inequality in the United States (Nielsen and Alderson 1997). In addition to a focus on globalization and the consequences of an increasingly integrated world economy, this literature has been typified in particular by an attention to the changing role of women, deindustrialization, and the role of labor market institutions in mediating the various pressures for growing inequality that have emerged in recent decades (e.g., Thurow 1987; Bluestone and Harrison 1982; Harrison and Bluestone 1988; Levy and Michel 1991; Levy and Murnane 1992; Ryscavage, Green, and Welniak 1992; Danziger and Gottschalk 1993; Wood 1994; Morris and Western 1999; Lindert 2000; Nielsen and Alderson 2001).

Two kinds of arguments have been made regarding the distributional consequences of the changing role of women. The first focuses on the implications of the upswing in female labor force participation that the past few decades have witnessed. Thurow (1987) views rising female labor force participation as a major cause of rising inequality. Female labor force participation, he suggests, has contributed to the increase in inequality by inflating the bottom of the earnings distribution-due to women's lower average earnings-and, due to assortative mating, by amplifying the advantage of high-income households and the disadvantage of poor ones when both spouses work. For Thurow, the prediction is clearly that female labor force participation will be associated with greater income inequality among households. Alternatively, Cancian, Danziger, and Gottschalk (1993), among others, have argued that, taking into account (household) income-specific rates of female labor force participation, the net effect of increased female labor force participation is to produce more families with incomes near the middle of the income distribution, leading to a reduction of inequality. ${ }^{12}$ We entertain both predictions and allow them to be adjudicated by the data.

A second strain of thinking on the distributional consequences of the changing role of women focuses on the rising proportion of households headed by women. In the case of the United States, Levy and Michel (1991), Ryscavage, Green, and Welniak (1992), and Nielsen and Alderson (1997) have identified the growth of female-headed households as a major factor in the inequality upswing. Their reasoning is quite simple: insofar as female-headed households have lower average incomes, their rising proportion inflates the proportion of poor households and increases inequality. Unfortunately, data limitations preclude us from testing this ar-

\footnotetext{
${ }^{12}$ In support of this interpretation, we find that the size of the female labor force had a negative effect on family income inequality across U.S. counties in 1980 and 1990 (Nielsen and Alderson 1997).
} 
American Journal of Sociology

gument. ${ }^{13}$ This is a potentially important omission, as all indications are that recent changes in household structure in OECD countries have had a measurable effect on income distribution (Gottschalk and Danziger 1984; Karoly 1993).

A good deal of attention has been given to the distributional consequences of the decline of manufacturing employment in OECD countries over the past two or three decades (Levy and Murnane 1992). For authors such as Bluestone and Harrison (1982; Harrison and Bluestone 1988), deindustrialization is viewed as a principal cause of the upswing in income inequality. As discussed above, this is because the manufacturing sector is typically characterized by higher average wages and a more equal distribution than the service sector, so transfers of jobs from manufacturing to services produces a larger share of low-wage jobs and greater inequality. We test the prediction that the \%labor force in manufacturing will have a negative effect on inequality. Note that deindustrialization is an integral part of the globalization argument, as it is often invoked as an intermediate mechanism to explain how aspects of globalization, such as dependence on southern imports or DI outflow, affect income inequality.

\section{Institutional Factors}

Wood (1994) suggests that labor market institutions play a key role in mediating the effects of globalization. While a number of scholars have questioned the empirical status of the inequality/unemployment trade-off that Wood proposes (e.g., Glyn and Salverda 2000; Schmitt and Mishel 2000; see also Bertola and Ichino 1995; Blank 1997), his assumption that such institutions affect the distribution of income in important ways is, we believe, sound. As the last few decades have witnessed notable deunionization and significant changes in the "social pact" between employers, workers, and the state in a good number of advanced industrial countries, we see solid prima facie grounds for exploring such links. We thus investigate the effects on inequality of (1) the presence of unions, (2) wage setting coordination, and (3) the decommodification of labor by the welfare state, while remaining agnostic on the trade-off question.

A number of authors (e.g., Freeman 1993; ILO 1996) have attributed a substantial part of the inequality upswing to the declining unionization, or "deunionization," that most advanced industrial countries have experienced in recent years (Western 1995). Inasmuch as unions tend to flatten

${ }^{13}$ There is little data on the proportion of households female-headed in many countries, particularly in earlier years. This fact, coupled with issues of comparability (due to definitional differences), make the task of assembling this seemingly straightforward measure extraordinarily difficult. 
the distribution of earnings among workers and to reduce the wage differential between blue- and white-collar workers, declining unionization should be associated with widening wage differentials and greater inequality among households. In the case of the United States, Freeman (1993) attributes $20 \%$ of the rise in earnings inequality among men to deunionization and, looking at the experience of all workers in 16 OECD countries across the 1980s, shows that the upswing in earnings inequality at the industry level was least pronounced in highly unionized countries. Transplanting this argument to the domain of income inequality at the household level, we expect to observe a negative relationship between union density and inequality.

The presence of unions represents one sort of institutional constraint on widening wage differentials. In addition, as a general indicator of the balance of power between the organizations of employers and employees, one might also expect the strength of corporatist arrangements to be negatively related to income inequality. "Corporatism" usually refers to a set of institutional arrangements designed to achieve cooperation and consensus between labor, capital, and the state in the setting of national economic and social policy (e.g., Schmitter 1974; Cameron 1984; Lehmbruch 1984; Marks 1986). Key for our purposes is the role of corporatist institutions in wage setting. ${ }^{14}$ In strongly corporatist contexts, in which bargaining is national in scope and wage guidelines are centrally fixed, we expect to observe a flatter distribution of earnings, a smaller bluecollar/white-collar wage differential, and, ultimately, lower household income inequality. In weakly corporatist contexts in which bargaining is fragmented and local, we expect to observe wider wage differentials within and across firms and industries and, ultimately, within nations. As Western (1995; table 2) documents, the last few decades have indeed witnessed an (notably uneven) erosion of national-level bargaining in the OECD countries (see also Wallerstein 1999). As the timing of this erosion

${ }^{14}$ As Kenworthy notes, "Although centralization of wage bargaining has received the bulk of attention in the literature, a variety of recent findings suggest that it is coordination of wage setting which is likely to matter most in affecting macroeconomic performance outcomes . . . . Centralization [i.e., a classical corporatist arrangement] is only one means, albeit an important one, of achieving wage coordination. Others include guidance of industry-level bargaining by a powerful, monopolistic union confederation (as in Austria), a high degree of union concentration coupled with extensive pattern-setting across industries (as in Germany), coordination by employer federations and large firms with limited union influence (as in Japan and Switzerland), and government imposition of a wage schedule or freeze (as in Belgium, Denmark and the Netherlands in various years)" (Kenworthy 2001b, p. 5; emphasis in original). The measure we employ (see below) takes these alternative means of achieving wage coordination into account. Thus, while our use of the measure is motivated by the literature on corporatism, it should not be strictly equated with it. 


\section{American Journal of Sociology}

appears to roughly coincide with the upswing in inequality in a number of countries, we test the hypothesis that wage setting coordination is negatively related to income inequality.

Finally, to the degree to which people are unwilling to accept low-wage jobs, pressures for wider wage differentials-whatever their source-will necessarily express themselves in a fashion other than rising inequality. We thus explore the extent to which welfare states that are strongly decommodifying act as an additional institutional constraint on widening wage differentials. "Decommodification" refers to the differing degrees to which individuals in different societies are able, given the same level of total social welfare expenditure, to opt out of the market while maintaining a "socially acceptable" standard of living (Esping-Andersen 1990). In assessing the level of the decommodification, one would assign a low decommodification score to a social welfare system that offered large benefits, but offered them-either as a result of means-tests, work requirements, prior contribution requirements, or a number of other builtin constraints on entitlement to the transfer-to only a limited number of individuals. In contrast, one would assign a high decommodification score to a social welfare system that, while offering smaller benefits, granted the (universal) right to a transfer on the basis of citizenship.

The effects of the decommodification of labor on the functioning of the labor market are fairly straightforward. As Esping-Andersen has remarked in regard to Sweden:

When, as in Sweden, on any given day approximately 15 percent of workers are absent yet paid to work, it is difficult to sustain the logic of a labor market guided solely by the pure exchange principle. A very large share of what is normally regarded as labor time is in fact "welfare time." The range of alternative choice is such that Swedes are relatively de-commodified: they do not just hand over their time to the employer; the employers' control of the purchased labor-commodity is heavily circumscribed. (EspingAndersen 1990, p. 156)

To the extent that decommodification circumscribes the purchase of labor in this fashion and raises the effective minimum wage, we expect to observe a negative relationship between decommodification and income inequality.

DATA

Data for the dependent variable, the Gini coefficient of income inequality, are drawn from Deininger and Squire's (1996) "high quality" data set, a compendium of data on income inequality that was assembled with the 
aim of maximizing intertemporal and cross-national comparability. For the countries under consideration, Deininger and Squire often join the LIS data discussed above with other income surveys that meet their criteria for inclusion. With two exceptions, data are defined consistently over time (within countries), the Gini coefficient is calculated on the basis of income, and coverage is national. ${ }^{15}$

Real GDP/capita (log base 10) is measured in U.S. dollars. Data are from the Penn World Tables Mark 5.6 (Summers and Heston 1991). To reduce the collinearity generated by the inclusion of real GDP and its square in one of the models, we deviated this variable from its median (4.047). This transformation reduces the correlation between a variable and its square (Koopmans 1987).

Sector dualism (log base 10) is calculated from figures for the percentage of the labor force in agriculture $(p)$ and agriculture's share of the gross domestic product $(L)$ as

$$
R_{L}=|p-L|
$$

It can be shown that this formula is a special case of the Gini coefficient for a system with only two income-receiving units, which can be derived from the general formula for the Gini given by Nygård and Sandström (1981, p. 292, eq. 8.10). The absolute value is taken to guarantee a positive value in the hypothetical case in which the agricultural sector is relatively more productive than the nonagricultural. Data on the \%labor force in agriculture (log base 10) are drawn from the OECD's Labour Force Statistics, 1967-1987, and Labour Force Statistics, 1973-1993 (OECD 1989, $1995 \mathrm{~b}$ ). Data on agriculture's share of gross domestic product are from the World Bank's World Tables (World Bank, various years).

The natural rate of population increase is calculated as the crude birth rate minus the crude death rate. Birth rates and death rates are drawn primarily from World Bank (1997), supplemented with data from the World Tables (World Bank, various years).

The secondary school enrollment ratio is measured as secondary school enrollment as a percentage of the population of secondary school age. Estimates are from the World Bank's World Tables (World Bank, various years).

Data on direct investment outflow/labor force (log base 10) are drawn from the IMF's Balance of Payments Statistics Yearbook (various years). This represents the book value of all investments made in a given year

${ }^{15}$ Early observations for Denmark (1976) and Germany (1969) are based on income net of taxes, while the remaining observations for both countries are gross of taxes. Excluding these observations from the analysis does not affect the results reported below. 
American Journal of Sociology

by nationals of country $x$ to acquire managerial interest in enterprises sited in countries other than $x$ (IMF 1977). Labor force data are from the OECD's Labour Force Statistics, 1967-1987, and Labour Force Statistics, 1973-1993 (OECD 1989; 1995b).

Southern import penetration/GDP (log base 10) is measured as manufactured imports from non-OECD, non-COMECON countries in current U.S. dollars. Manufactured imports are defined as Standard International Trade Classification (SITC) groups 5, 6, 7, and 8. Import data are from the OECD's Foreign Trade by Commodities series (various years). Current GDP in U.S. dollars is drawn from the OECD's National Accounts (various years).

The net migration rate is calculated indirectly from figures for population and the crude birth and death rates, and is expressed per 1,000 population. Data are drawn primarily from World Bank (1997), supplemented with data from the World Tables (World Bank, various years).

Decommodification is measured as an index of decommodification in sickness, maternity, and unemployment programs. The measurement scheme is inspired by Esping-Andersen (1990, p. 54) and is described in detail in Alderson (1997). Decommodification in sickness, maternity, and unemployment programs is measured in terms of (1) the replacement rate-ratio of benefits to usual earnings-for an average production worker in the first 26 weeks of sickness, maternity, or unemployment, (2) the number of weeks of employment required to qualify for benefits, (3) the number of waiting days before benefits are paid, and (4) the number of weeks that benefits can be maintained. These individual items are standardized and then summed to arrive at decommodification scores for each of the three programs. The overall decommodification measure is an index of decommodification in each of the three programs. ${ }^{16}$ Nations with high values on the summary decommodification index are nations that offer sickness, maternity, and unemployment programs with high replacement rates, require little (or no) employment to qualify for benefits, require no waiting period before benefits are paid, and offer benefits for long periods of time. Nations with low values are nations that offer low replacement rates, require extensive periods of employment to qualify for

\footnotetext{
${ }^{16}$ Our measure departs from Esping-Andersen's (1990) in two ways. First, our summary measure includes decommodification in maternity programs and excludes decommodification in old age insurance. We do this to focus the measure on the options open to the economically active population, female and male. Second, data limitations mean that we are unable to weight each individual index (i.e., sickness, maternity, unemployment) by the percentage of the relevant population covered by the program in each year. Taking these differences into account, we find that there is nonetheless a high degree of agreement between our summary index and that presented by EspingAndersen (1990, p. 52) for $1980(r=.902 ; N=16)$.
} 
benefits, require long waiting periods before benefits are paid, and offer benefits for short periods of time. Alternatively, nations can score low if they do not offer a given program or offer programs on a means-tested basis. Data are from the U.S. Department of Health and Human Services (various years).

Data on wage-setting coordination are from an unpublished paper that was kindly provided by Lane Kenworthy (2001b). The measure draws on Soskice (1990), Golden et al., ${ }^{17}$ Iversen (1999), and the European Industrial Relations Review (various issues). Wage-setting coordination is measured as an index with five categories, ranging from " 1 " when wage bargaining is fragmented (i.e., confined to individual firms or plants) to "5" when wage bargaining is highly coordinated. High degrees of coordination can be achieved through classical tripartite corporatist arrangements (e.g., Sweden), through coordination of industry bargaining by a central union confederation (e.g., Austria), or through coordination of bargaining by employer organizations (e.g., Japan). Details regarding the index and the motivation for the scoring appear in Kenworthy (2001b; see also Hicks and Kenworthy 1998).

Union density is measured as the gross union density rate (total union members as a percentage of total wage and salaried employees). Data for the 1970-92 period are from an unpublished paper that was kindly provided by Jelle Visser (1996). Data for the 1967-69 period are from Visser (1989), Bain and Price (1980), and various country yearbooks.

The female labor force participation rate is expressed as the size of the female labor force as a percentage of the female population ages 15-64. Data are from the OECD $(1989,1995 b)$.

Data on the \%labor force in manufacturing are drawn primarily from the OECD's Labour Force Statistics, 1967-1987 and Labour Force Statistics, 1973-1993 (OECD 1989, 1995b). Cases not covered in this source (i.e., Netherlands, 1967-74) are coded with data drawn from the U.S. Bureau of Labor Statistics (BLS 1993).

Two period indicators (1973-81 and 1982-92, with the 1967-72 period as the baseline) are included in most of the models we estimate to capture time-specific effects. These indicators trace, respectively, the period from the trough of the 1973-74 global recession to the brink of the recession of the early 1980s, and the period from the trough of the 1981-82 recession to the brink of the global recession of the early 1990s.

\footnotetext{
${ }^{17}$ See Miriam Golden, Michael Wallerstein, and Peter Lange, 1997, "Union Centralization among Advanced Industrial Societies: An Empirical Study." Dataset available at http://www.shelley.polisci.ucla.edu/data.
} 
American Journal of Sociology

METHODS

Unbalanced Panel Data

The data set contains a maximum of 192 observations made between 1967 and 1992. These are distributed between 16 countries in the manner indicated in figure A1. The data are unbalanced, with countries contributing different numbers of observations, and the time span between observations is irregular, varying across countries and time points. In this section, we discuss potential problems associated with this type of data and the measures we have taken to minimize their impact on model estimation.

\section{Correlation of Errors}

As mentioned earlier, the inequality data that we have assembled may not be strictly appropriate for level comparisons. Definitions of basic concepts (i.e., income, household) may vary in important ways across countries, as may methods of treating factors such as household size and taxes and transfers. ${ }^{18}$ Such systematic and unmeasured differences in the measurement of income inequality across countries will be forced in the error term of the regression model, causing errors pertaining to the same country at different time points to be correlated. In the panel context, such a pattern of correlation among errors renders ordinary least squares (OLS) estimation inconsistent (heterogeneity bias) and inefficient and causes standard errors of the estimates to be underestimated (Hsiao 1986; Greene 1993).

Systematic measurement differences may be modeled, by first approximation, as an unmeasured country-specific and time-invariant component that affects income inequality in the same way in a given country at all time points. Other time-invariant unmeasured factors (other than measurement procedures) that differ across countries could also contribute to that country-specific component. The presence of an unmeasured timeinvariant, country-specific factor causes the errors corresponding to different observations on the same country to be correlated by the same amount, denoted $\rho$. Thus the unmeasured country-specific factor causes the variance-covariance matrix of the errors to have a block-diagonal structure in which errors pertaining to observations on the same country are correlated by an amount $\rho$, while observations pertaining to different countries are uncorrelated. Two general approaches to estimating models with unmeasured country-specific components can be used, the fixedeffects model (FEM) and the random-effects model (REM), which have

${ }^{18}$ See Deininger and Squire (1996) for a discussion of the cross-national comparability of the inequality data assembled in their compendium. 
been discussed in Nielsen and Alderson (1995) and Gustafsson and Johansson (1999).

The FEM differs from the more familiar ordinary least squares procedure (OLS) in its treatment of the intercept. Where, under OLS, all countries are constrained to the same intercept, in the FEM, indicator variables are introduced for each country to represent country-specific intercepts. By doing so, one "simulates" unmeasured time-invariant, country-specific factors and thereby addresses the heterogeneity bias. It can be shown that estimating the model with $n$ country indicators is equivalent to using OLS with the data deviated from the country-specific means (e.g., Hsiao 1986). As the FEM estimation algorithm assigns all between-country variation to the indicator variables for country, estimates of the relationships of interest are not directly influenced by level differences. Only within-country (intertemporal) variation remains. The FEM is thus extremely conservative (but also profligate), as it "throws out" all betweencountry variation in the data. Furthermore, FEM does not allow estimation of the effects of variables that are constant over time for a given country, as these are exactly collinear with the set of country-specific indicators. Correspondingly, estimation of the effects of variables that are largely (if not exactly) constant for a given country over time, in the sense that they vary mostly across countries, is rendered imprecise in the FEM because of collinearity with the country indicators.

The REM treats the country-specific components as part of the error term of the model, rather than as a fixed country-specific intercept, as in the FEM. Estimating the REM is equivalent to using OLS after transforming the data by removing a fraction of the country-specific means (rather than the whole mean, as in the FEM). Thus the REM is less wasteful of between-country variation than the FEM, and additionally allows estimation of the effects of variables that are constant over time for a given country. We found that much of the variation of substantive interest in this data set was variation between countries, rather than over time, and that some of the most important explanatory factors are institutional features of countries that vary little over time. For these reasons, we present the REM estimates. ${ }^{19}$ We implement the REM with a variant of the generalized linear model, the xtgee procedure, which is available in the statistical program STATA (StataCorp 1997; Liang and Zeger 1986). We specify the error structure as exchangeable, which assumes that the correlations among errors corresponding to the same country are the same and equal to $\rho$. This procedure estimates $\rho$ and the regression coefficients

${ }^{19}$ For additional considerations regarding the choice of REM over FEM, see Greene (1993, chap. 16), Nielsen and Alderson (1995), and Gustafsson and Johansson (1999). 
American Journal of Sociology

simultaneously. ${ }^{20}$ In addition, we apply robust estimates of the standard errors of the estimate using the Huber/White/sandwich formula, which are valid even if the within-group correlations are not as hypothesized by the specified correlation structure (see StataCorp [1997] for details).

Error terms in a panel may also be correlated because of unmeasured influences that affect all countries in a similar way at a given time point. The general state of the world economy might affect inequality in all countries in such a synchronous fashion. In the analysis, we address this possibility by introducing the time-specific factor explicitly into the models in the form of period indicators for 1973-81 and for 1982-92, with the 1967-72 period as the reference category. The substantive basis for the choice of periods was discussed earlier. This strategy amounts, as it were, to using the FEM approach to handle unmeasured time-specific factors.

When the data consist of a single time series, the classical approach to correlated errors is to assume an autoregressive error structure of the first order (AR[1]), which can then be estimated using, for example, the Cochrane-Orcutt approach (Neter et al. 1996, chap. 12). It is possible in principle to adapt the Cochrane-Orcutt methodology to panel data to estimate an AR(1) model of the residual error term that is left over after removing the country-specific error, as well as the period-specific effects. We do not do so in this project because (1) the major mechanisms causing correlation of the errors are already captured by the REM assumption of an unmeasured country-specific component of the error, and by the explicit introduction of the period indicators, so that the remaining autocorrelation of the $\operatorname{AR}(1)$ is likely to be small, if it exists at all; (2) the typical length of the time series for the countries in the data set is too short to support estimation of the AR(1) structure (see Beck and Katz's [1995] discussion of the Parks-Kmenta model); (3) estimating the autoregressive parameter by the Cochrane-Orcutt method consumes the first period of observation for each country, substantially reducing the degrees of freedom of the model; (4) the unbalanced structure of the data, with unequal time intervals between observations, is not suitable for AR(1) estimation; and (5) as has been known for a long time, panel models that incorporate both a unit-specific component and an autoregressive structure of the residual error tend to be highly sensitive to small departures from model assumptions (i.e., they are not robust; Drummond and Gallant 1979).

\footnotetext{
${ }^{20}$ The $x$ tgee estimates are asymptotically equivalent to generalized least squares estimates but not necessarily numerically identical, especially in unbalanced panels.
} 
Income Inequality Trends

Tests of Significance and Measure of Fit

As we have developed clear directional hypotheses for most of the independent variables in the regression models and we employ conservative robust standard errors, we use one-tailed tests of the regression estimates, and we indicate coefficients significant at the 0.10 level or better. For symmetry, we also use one-tailed tests with one variable for which there is no single directional hypothesis (female labor force participation) and when the sign of the coefficient estimate contradicts the directional hypothesis (i.e., the result is nonsignificant in principle in a one-tailed framework). Since we also provide the $t$-ratios, interested readers can carry out their own significance tests at any desired level of significance by comparing them to a standard normal distribution.

The generalized linear model estimation procedure does not provide an $R^{2}$ measure of fit. To give a very crude indication of the fit of a model, we calculated a substitute $R^{2}$ as the squared correlation of the predicted and actual values of the dependent variable. The substitute $R^{2}$ has limited usefulness, however, as it underestimates the actual fit of the model and cannot be used to compare the relative fits of different models. Therefore we do not involve the $R^{2}$ estimates in the discussion of the results.

\section{Multivariate Outliers}

Outliers and influential cases are often a problem with cross-national data. Diagnostic tools such as Studentized residuals, Cook's D, and partial regression plots are available to identify such cases (Belsley, Kuh, and Welsch 1980; Bollen and Jackman 1985; Wilkinson 1990a, 1990b). These classical diagnostics are strictly justified only for situations in which a single observation is problematic. Thus we use a newer, robust outlier detection algorithm that is appropriate even when several observations are outlying or influential (Hadi 1992, 1994). ${ }^{21}$ Applying the Hadi procedure in the context of OLS estimation with the pooled data set, we identified five outliers and have excluded these from the analysis. ${ }^{22}$

\footnotetext{
${ }^{21}$ The Hadi robust outlier detection algorithm is available in SYSTAT and STATA.

${ }^{22}$ Australia 1990, Belgium 1992, France 1967, Italy 1974, and Sweden 1992 were identified as outliers by the Hadi $(1992,1994)$ procedure in a number of the models. Substantively, the only notable consequence of excluding these cases from the analysis is that it reduces the size of the southern import penetration coefficient by nearly $50 \%$. To err on the side of caution, we have excluded these observations from the analysis. The time-period indicators were excluded in carrying out the Hadi procedure, as these variables cannot satisfy the assumption of multivariate normality.
} 
American Journal of Sociology

\section{RESULTS: MODELS OF INCOME INEQUALITY IN ADVANCED INDUSTRIAL SOCIETIES}

Correlations and basic statistics are presented in table 1 . Regression results are presented in tables 2, 3, 4, and 5 .

\section{The Great U-Turn on Inequality}

The relationship between inequality and development is described in model 1, which represents income inequality as a simple function of development measured as the logarithm (base 10) of real GDP/capita and its square. Model 1 is the numerical counterpart to the U-turn represented graphically in figure 1 . Here the curvilinear, $U$-shaped relationship shown in that figure is approximated with a quadratic function of development. As one can note, the coefficient of the squared term is positive, consistent with the U-turn hypothesis, indicating that among these industrial societies inequality has first declined then turned to rise with development. ${ }^{23}$ However, the real GDP/capita quadratic is significant at just the $10 \%$ level. We thus find only modest evidence in support of the idea that increasing inequality is an inherent feature of postindustrial development; that is, that there is a systematic propensity for the most developed countries to experience an upturn in inequality beyond a certain level of development. Clearly, the inequality experience of the advanced industrial countries in recent decades has been shaped by more than processes of economic development alone.

\section{The Core Model}

Model 2 introduces the core model of income inequality along with two period indicators. ${ }^{24}$ It was suggested above that three major processes underlying the inverted $U$-shaped relationship of inequality with development observed by Kuznets can be captured with four variables: sector dualism, \%labor force in agriculture, natural rate of increase, and secondary school enrollment ratio. Previous research has shown that the core model explains a substantial proportion of the variance in inequality

\footnotetext{
${ }^{23}$ Finding the vertex of the parabola, the regression coefficients in model 1 indicate that the value of real GDP per capita beyond which income inequality begins to rise is $\$ 10,032$ (in 1985 prices). This is very close to the vertex of the nonparametric LOESS regression plotted in fig. 1 and is approximately the level of development reached by the United Kingdom and New Zealand in 1978.

${ }^{24}$ Variance inflation factors (VIF) were calculated for the OLS analogues of models 2-13. All individual VIF were below the cutoff of 10 that is typically suggested to indicate a serious problem with collinearity and no mean VIF was considerably larger than 1 (Neter et al. 1996).
} 
TABLE 1

Correlations and Basic Statistics for Variables in the ANalysis of Income Inequality

\begin{tabular}{|c|c|c|c|c|c|c|c|c|c|c|c|c|c|c|}
\hline & 1 & 2 & 3 & 4 & 5 & 6 & 7 & 8 & 9 & 10 & 11 & 12 & 13 & 14 \\
\hline $1 . \quad \ldots \ldots \ldots$ & $\ldots$ & & & & & & & & & & & & & \\
\hline 2. $\ldots \ldots \ldots$ & .135 & & & & & & & & & & & & & \\
\hline 3. $\ldots \ldots \ldots$ & .458 & -.484 & & & & & & & & & & & & \\
\hline 4. ......... & .421 & -.567 & .813 & & & & & & & & & & & \\
\hline $5 . \ldots \ldots \ldots$ & .435 & -.153 & .229 & .351 & & & & & & & & & & \\
\hline 6. ......... & -.018 & .500 & -.213 & -.184 & .024 & & & & & & & & & \\
\hline 7. ......... & -.253 & .605 & -.519 & -.592 & -.394 & .419 & & & & & & & & \\
\hline 8. $\ldots \ldots \ldots$ & -.085 & .504 & -.453 & -.564 & -.219 & .279 & .631 & & & & & & & \\
\hline 9. ......... & .124 & .349 & -.163 & -.171 & .209 & .093 & .077 & -.023 & & & & & & \\
\hline $10 . \ldots \ldots \ldots$ & -.294 & -.120 & -.050 & .140 & -.519 & -.015 & .113 & -.068 & -.168 & & & & & \\
\hline $11 . \ldots \ldots \ldots$ & -.091 & -.469 & .381 & .418 & -.095 & -.016 & -.182 & -.220 & -.213 & .358 & & & & \\
\hline $12 . \ldots \ldots \ldots$ & -.393 & -.265 & .243 & .222 & -.557 & .060 & .153 & -.109 & -.199 & .544 & .462 & & & \\
\hline $13 . \ldots \ldots \ldots$ & -.031 & .507 & -.308 & -.313 & -.212 & .460 & .445 & .248 & .014 & .379 & -.042 & .075 & & \\
\hline $14 . \ldots \ldots \ldots$ & -.317 & -.588 & .136 & .090 & -.286 & -.517 & -.433 & -.420 & -.244 & .155 & .300 & .187 & -.206 & $\ldots$ \\
\hline Min ......... & 22.900 & 3.734 & .005 & .322 & -2.400 & 59.600 & .000 & .087 & -8.600 & 16.780 & 1.000 & 7.000 & 32.000 & 14.542 \\
\hline Max ........ & 44.000 & 4.258 & 1.114 & 1.382 & 12.700 & 121.000 & 2.509 & .655 & 10.240 & 100.350 & 5.000 & 39.000 & 80.549 & 37.939 \\
\hline Mean ...... & 32.360 & 4.063 & .474 & .796 & 5.157 & 88.603 & 1.202 & .320 & 1.584 & 48.950 & 2.963 & 24.968 & 55.907 & 22.901 \\
\hline SD . ........ & 4.053 & .099 & .298 & .257 & 3.559 & 9.993 & .489 & .116 & 3.112 & 21.504 & 1.598 & 8.910 & 11.354 & 4.641 \\
\hline
\end{tabular}

Note. - 1. Gini income inequality; 2. Real GDP/capita (log base 10); 3. Sector dualism (log base 10); 4. \%LF in agriculture (log base 10); 5. Natural rate of population increase; 6 . Secondary school enrollment ratio; 7. DI outflow/labor force (log base 10); 8. Southern import/GDP (log base 10); 9 . Net migration rate; 10. Union density; 11 . 


\section{American Journal of Sociology}

TABLE 2

Regression Models of Income Inequality (Gini $\times$ 100): Generalized Linear Model Estimates For 16 OECD Nations, 1967-92

\begin{tabular}{|c|c|c|c|c|}
\hline \multirow[b]{2}{*}{ VARIABLE } & \multicolumn{4}{|c|}{ ModeL } \\
\hline & 1 & 2 & 3 & 4 \\
\hline Real GDP/capita ${ }^{\mathrm{a}, \mathrm{b}} \quad \ldots \ldots \ldots \ldots$ & $\begin{array}{r}-298.198 * \\
(-1.568)\end{array}$ & & & \\
\hline Real GDP/capita ${ }^{2} \ldots \ldots \ldots \ldots \ldots$ & $\begin{array}{c}37.262 * \\
(1.558)\end{array}$ & & & \\
\hline Sector dualism ${ }^{\mathrm{a}}$ & & $\begin{array}{l}2.434 * * \\
(1.644)\end{array}$ & $\begin{array}{l}1.510 \\
(.985)\end{array}$ & $\begin{array}{l}-.071 \\
(-.042)\end{array}$ \\
\hline$\%$ labor force in agriculture ${ }^{\mathrm{a}} \ldots$ & & $\begin{array}{c}3.864 \\
(1.251)\end{array}$ & $\begin{array}{l}8.696^{* *} \\
(1.805)\end{array}$ & $\begin{array}{l}7.907 * * \\
(2.474)\end{array}$ \\
\hline $\begin{array}{l}\text { Natural rate of population } \\
\text { increase } \ldots \ldots \ldots \ldots \ldots \ldots \ldots\end{array}$ & & $\begin{array}{r}.330 * \\
(1.416)\end{array}$ & $\begin{array}{r}.339^{*} \\
(1.408)\end{array}$ & $\begin{array}{c}.317 \\
(1.127)\end{array}$ \\
\hline $\begin{array}{l}\text { Secondary school enrollment } \\
\quad \text { ratio } \ldots \ldots \ldots \ldots \ldots \ldots \ldots \ldots\end{array}$ & & $\begin{array}{l}-.059 * * \\
(-1.777)\end{array}$ & $\begin{array}{l}-.079 * * \\
(-2.379)\end{array}$ & $\begin{array}{l}-.059 * * \\
(-1.858)\end{array}$ \\
\hline DI outflow/labor force ${ }^{\mathrm{a}} \ldots \ldots \ldots$ & & & $\begin{array}{l}2.341 * * \\
(2.479)\end{array}$ & \\
\hline $\begin{array}{l}\text { Southern import penetration/ } \\
\qquad \operatorname{GDP}^{\mathrm{a}} \ldots \ldots \ldots \ldots \ldots \ldots \ldots \ldots\end{array}$ & & & & $\begin{array}{l}6.886 * * * \\
(2.343)\end{array}$ \\
\hline 1973-81 period indicator $\ldots \ldots$ & & $\begin{array}{l}2.434^{* *} \\
(2.325)\end{array}$ & $\begin{array}{l}1.917 * * \\
(2.104)\end{array}$ & $\begin{array}{c}1.274 \\
(1.105)\end{array}$ \\
\hline 1982-92 period indicator . ...... & & $\begin{array}{l}3.872 * * * \\
(4.013)\end{array}$ & $\begin{array}{l}1.917 * * * \\
(3.246)\end{array}$ & $\begin{array}{l}2.449 * \\
(1.554)\end{array}$ \\
\hline Constant $\ldots \ldots \ldots \ldots \ldots \ldots \ldots$ & $\begin{array}{l}32.350 * * * \\
(37.137)\end{array}$ & $\begin{array}{l}29.233^{* * * *} \\
(6.261)\end{array}$ & $\begin{array}{l}25.084 * * * \\
(3.998)\end{array}$ & $\begin{array}{l}26.031 * * * \\
(6.223)\end{array}$ \\
\hline 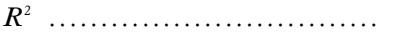 & .109 & .338 & .269 & .324 \\
\hline 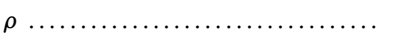 & .679 & .558 & .627 & .637 \\
\hline
\end{tabular}

among countries at different levels of economic development (e.g., Nielsen and Alderson 1995).

The effect on inequality of the shift of the labor force out of agriculture over the course of development is captured with sector dualism (log base 10) and the \%labor force in agriculture (log base 10). Sector dualism measures inequality resulting from differences in average income between the agricultural and nonagricultural sectors. We expect that it will have a positive effect on inequality. Net of sector dualism, the \%labor force in agriculture is expected to have a negative effect, because it captures the 
Income Inequality Trends

TABLE 3

Regression Models of Income Inequality (Gini $\times 100$ ): Generalized Linear Model Estimates For 16 OECD Nations, 1967-92

\begin{tabular}{|c|c|c|c|c|}
\hline \multirow[b]{2}{*}{ VARIABLE } & \multicolumn{4}{|c|}{ MODEL } \\
\hline & 5 & 6 & 7 & 8 \\
\hline Sector dualism ${ }^{\mathrm{a}} \ldots \ldots$ & $\begin{array}{l}2.439 * * \\
(1.660)\end{array}$ & $\begin{array}{l}1.245 \\
(.846)\end{array}$ & $\begin{array}{l}2.784 * * \\
(1.949)\end{array}$ & $\begin{array}{l}2.392 * \\
(1.414)\end{array}$ \\
\hline$\%$ labor force in agriculture ${ }^{a} \ldots$ & $\begin{array}{l}3.920 \\
(1.249)\end{array}$ & $\begin{array}{l}6.137 * * * \\
(2.316)\end{array}$ & $\begin{array}{l}4.479 * \\
(1.588)\end{array}$ & $\begin{array}{l}4.546^{*} \\
(1.597)\end{array}$ \\
\hline $\begin{array}{l}\text { Natural rate of population } \\
\quad \text { increase } \ldots \ldots \ldots \ldots \ldots \ldots \ldots \ldots\end{array}$ & $\begin{array}{r}.326 * \\
(1.400)\end{array}$ & $\begin{array}{l}.204 \\
(.997)\end{array}$ & $\begin{array}{c}.278 \\
(1.202)\end{array}$ & $\begin{array}{c}.225 \\
(1.001)\end{array}$ \\
\hline $\begin{array}{l}\text { Secondary school enrollment } \\
\quad \text { ratio } \ldots \ldots \ldots \ldots \ldots \ldots \ldots \ldots \ldots\end{array}$ & $\begin{array}{l}-.059 * * \\
(-1.762)\end{array}$ & $\begin{array}{c}-.029 \\
(-1.009)\end{array}$ & $\begin{array}{l}-.056 * * \\
(-1.714)\end{array}$ & $\begin{array}{l}-.030 \\
(-.934)\end{array}$ \\
\hline Net migration rate $\ldots \ldots \ldots \ldots$ & $\begin{array}{c}.015 \\
(.168)\end{array}$ & & & \\
\hline Union density $\ldots \ldots \ldots \ldots \ldots \ldots$ & & $\begin{array}{l}-.084 * * * \\
(-2.439)\end{array}$ & & \\
\hline Wage setting coordination ..... & & & $\begin{array}{l}-.486 * * \\
(-2.663)\end{array}$ & \\
\hline Decommodification ............ & & & & $\begin{array}{l}-.146^{* * *} \\
(-2.211)\end{array}$ \\
\hline 1973-81 period indicator $\ldots .$. & $\begin{array}{l}2.129 * * \\
(2.316)\end{array}$ & $\begin{array}{l}1.762 * * \\
(1.884)\end{array}$ & $\begin{array}{l}2.110 * * \\
(2.387)\end{array}$ & $\begin{array}{l}1.936 * * \\
(2.170)\end{array}$ \\
\hline 1982-92 period indicator $\ldots \ldots$ & $\begin{array}{l}3.873^{* * * *} \\
(4.030)\end{array}$ & $\begin{array}{l}3.361^{* * * *} \\
(3.481)\end{array}$ & $\begin{array}{l}3.551^{* * * *} \\
(4.068)\end{array}$ & $\begin{array}{l}3.516^{* * * *} \\
(3.942)\end{array}$ \\
\hline Constant $\ldots \ldots \ldots \ldots \ldots \ldots \ldots \ldots$ & $\begin{array}{l}29.162 * * * \\
(6.203)\end{array}$ & $\begin{array}{l}30.758 * * * \\
(7.754)\end{array}$ & $\begin{array}{l}30.223 * * * \\
(6.783)\end{array}$ & $\begin{array}{l}30.745 * * * \\
(6.301)\end{array}$ \\
\hline$R^{2} \quad \ldots \ldots \ldots \ldots \ldots \ldots \ldots \ldots \ldots \ldots \ldots \ldots \ldots$ & .341 & .365 & .377 & .498 \\
\hline$\rho \ldots \ldots \ldots \ldots \ldots \ldots \ldots \ldots \ldots \ldots \ldots \ldots \ldots \ldots$ & .556 & .552 & .551 & .523 \\
\hline
\end{tabular}

effect of comparatively low inequality within the agricultural sector. As one can note from the results of model 2, only the first prediction is supported. While the coefficient of sector dualism is correctly signed and significant, the coefficient of \%labor force in agriculture is nonsignificant and positive. We conclude that while sector dualism continues to affect inequality in the advanced industrial societies, inequality within the agricultural sector is no longer significantly lower than in the nonagricultural sector.

The natural rate of population increase is expected to affect inequality directly by affecting the age distribution of the labor force-and thus the 


\section{American Journal of Sociology}

TABLE 4

Regression Models of Income Inequality (Gini $\times$ 100): Generalized Linear Model Estimates For 16 OECD Nations, 1967-92

\begin{tabular}{|c|c|c|c|}
\hline \multirow[b]{2}{*}{ VARIABLE } & \multicolumn{3}{|c|}{ MODEL } \\
\hline & 9 & 10 & 11 \\
\hline Sector dualism ${ }^{\mathrm{a}}$ & $\begin{array}{c}2.183^{*} \\
(1.551)\end{array}$ & $\begin{array}{c}1.665 \\
(1.179)\end{array}$ & $\begin{array}{c}-.931 \\
(-.595)\end{array}$ \\
\hline \%labor force in agriculture ${ }^{a}$ & $\begin{array}{l}5.499 * * \\
(1.743)\end{array}$ & $\begin{array}{c}5.323 * \\
(1.640)\end{array}$ & $\begin{array}{l}12.598 * * * \\
(3.041)\end{array}$ \\
\hline Natural rate of population increase ... & $\begin{array}{c}.295 \\
(1.236)\end{array}$ & $\begin{array}{c}.183 \\
(.815)\end{array}$ & $\begin{array}{c}.281 \\
(1.027)\end{array}$ \\
\hline Secondary school enrollment ratio $\ldots$ & $\begin{array}{l}-.084 * * * \\
(-2.857)\end{array}$ & $\begin{array}{l}-.093 * * * \\
(-2.506)\end{array}$ & $\begin{array}{l}-.072 * * \\
(-2.196)\end{array}$ \\
\hline Female labor force participation $\ldots .$. & $\begin{array}{c}.107 * * * \\
(2.889)\end{array}$ & & \\
\hline \%labor force in manufacturing ........ & & $\begin{array}{l}-.397 * * * \\
(-2.351)\end{array}$ & \\
\hline DI outflow/labor force ${ }^{\mathrm{a}} \ldots \ldots \ldots \ldots \ldots$ & & & $\begin{array}{l}1.772 * * \\
(1.832)\end{array}$ \\
\hline Southern import penetration/GDP ${ }^{\mathrm{a}} \ldots$ & & & $\begin{array}{l}7.501 * * \\
(2.691)\end{array}$ \\
\hline Net migration rate $\ldots \ldots \ldots \ldots \ldots \ldots \ldots$ & & & $\begin{array}{l}.102 * * \\
(2.477)\end{array}$ \\
\hline $1973-81$ period indicator $\ldots \ldots \ldots \ldots \ldots$ & $\begin{array}{l}1.793 * * \\
(2.188)\end{array}$ & $\begin{array}{c}1.010 \\
(1.133)\end{array}$ & $\begin{array}{c}1.012 \\
(1.046)\end{array}$ \\
\hline 1982-92 period indicator $\ldots \ldots \ldots \ldots \ldots$ & $\begin{array}{l}2.949 * * * \\
(3.071)\end{array}$ & $\begin{array}{c}1.385^{*} \\
(1.347)\end{array}$ & $\begin{array}{c}1.875 * \\
(1.495)\end{array}$ \\
\hline 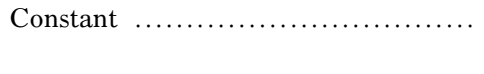 & $\begin{array}{l}25.093 * * * \\
(4.652)\end{array}$ & $\begin{array}{l}42.756 * * * \\
(6.057)\end{array}$ & $\begin{array}{l}21.826 * * * \\
(4.189)\end{array}$ \\
\hline 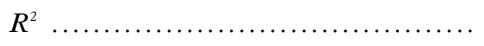 & .318 & .372 & .281 \\
\hline 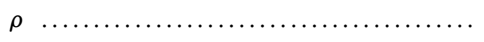 & .583 & .583 & .685 \\
\hline
\end{tabular}

supply of young, unskilled labor-and indirectly as a proxy for generalized sociocultural dualism. We thus expect that the natural rate of increase (births minus deaths) will have a positive effect on inequality. The results of model 2 lend support to this prediction. The natural rate of increase is found to have a positive effect on income inequality. This result indicates that the demographic transition (and the general social heterogeneity that it is argued to proxy) continues to define the inequality experience of societies that are well into its latter stages.

The third major feature of development incorporated in the core model is the diffusion of education (skills deepening). The classical expectation 
TABLE 5

Regression Models of INCOME INEquality (Gini $\times 100$ ): Generalized Linear Model Estimates for 16 OECD Nations, 1967-92

\begin{tabular}{|c|c|c|}
\hline \multirow[b]{2}{*}{ VARIABLE } & \multicolumn{2}{|c|}{ MODEL } \\
\hline & 12 & 13 \\
\hline Sector dualism ${ }^{\mathrm{a}} \ldots \ldots \ldots \ldots \ldots \ldots \ldots \ldots \ldots \ldots$ & $\begin{array}{l}-1.879 \\
(-1.148)\end{array}$ & $\begin{array}{l}-1.543 \\
(-.937)\end{array}$ \\
\hline \%labor force in agriculture ${ }^{\mathrm{a}}$ & $\begin{array}{l}15.032 * * * \\
(4.267)\end{array}$ & $\begin{array}{l}13.885 * * * \\
(3.696)\end{array}$ \\
\hline Natural rate of population increase $\ldots$ & $\begin{array}{l}.089 \\
(.435)\end{array}$ & $\begin{array}{l}.018 \\
(.100)\end{array}$ \\
\hline Secondary school enrollment ratio .... & $\begin{array}{l}-.019 \\
(-.812)\end{array}$ & $\begin{array}{r}-.043^{*} \\
(-1.604)\end{array}$ \\
\hline DI outflow/labor force ${ }^{a}$ & $\begin{array}{l}1.682^{* *} \\
(2.079)\end{array}$ & $\begin{array}{c}1.038^{*} \\
(1.288)\end{array}$ \\
\hline Southern import penetration/GDP ${ }^{\mathrm{a}}$. & $\begin{array}{l}7.679^{* * *} \\
(2.914)\end{array}$ & $\begin{array}{l}5.560^{*} \\
(1.608)\end{array}$ \\
\hline Net migration rate $\ldots \ldots \ldots \ldots \ldots \ldots \ldots$ & $\begin{array}{l}.108^{* *} \\
(2.323)\end{array}$ & $\begin{array}{l}.129 * * * \\
(2.529)\end{array}$ \\
\hline Union density & $\begin{array}{l}-.088^{* *} \\
(-2.116)\end{array}$ & $\begin{array}{l}-.083 * * \\
(-2.266)\end{array}$ \\
\hline Wage setting coordination ......... & $\begin{array}{l}-.331 * * \\
(-2.265)\end{array}$ & $\begin{array}{l}-.272 * * \\
(-2.256)\end{array}$ \\
\hline Decommodification $\quad \ldots \ldots \ldots \ldots \ldots \ldots \ldots$ & $\begin{array}{l}-.093 * * \\
(-1.643)\end{array}$ & $\begin{array}{r}-.092 * \\
(-1.496)\end{array}$ \\
\hline Female labor force participation $\ldots . .$. & & $\begin{array}{r}.056^{*} \\
(1.442)\end{array}$ \\
\hline \%labor force in manufacturing ........ & & $\begin{array}{c}-.167 \\
(-1.176)\end{array}$ \\
\hline 1973-81 period indicator $\ldots \ldots \ldots \ldots \ldots$ & $\begin{array}{c}.466 \\
(.534)\end{array}$ & $\begin{array}{c}.115 \\
(.150)\end{array}$ \\
\hline 1982-92 period indicator & $\begin{array}{l}.849 \\
(.855)\end{array}$ & $\begin{array}{l}-.065 \\
(-.076)\end{array}$ \\
\hline Constant & $\begin{array}{l}25.499 * * * \\
(6.017)\end{array}$ & $\begin{array}{l}31.043 * * * \\
(4.820)\end{array}$ \\
\hline 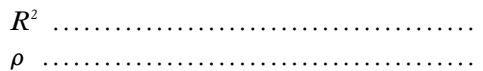 & $\begin{array}{l}.439 \\
.677\end{array}$ & $\begin{array}{l}.516 \\
.600\end{array}$ \\
\hline
\end{tabular}

Note.-Numbers in parentheses are $t$-values. $N=184$.

${ }^{a}$ Log base 10 .

* $P<.10$, one-tailed test

** $P<.05$.

$* * * P<.01$ 


\section{American Journal of Sociology}

is that the spread of education with development will have a negative effect on inequality. As education diffuses throughout the population, the supply of skilled workers will increase, reducing the wage differential between the skilled and unskilled. The results of model 2 confirm this hypothesis. The secondary school enrollment ratio has a significant negative effect on income inequality. Crenshaw and Ameen (1994) propose that the relationship between the diffusion of education and inequality turns to become positive at high levels of educational expansion. While inspection of the partial plots does reveal some suggestion of curvilinearity in the relationship between inequality and the secondary school enrollment ratio, it does not appear pronounced. When this is approximated as a second-degree polynomial of the secondary school enrollment ratio (not shown), the squared term is found to be insignificant. We conclude from this that the average level of education continues to exert an important negative influence on income inequality in the advanced industrial societies. ${ }^{25}$

As regards the period indicators, one can note that both the 1973-81 and 1982-92 indicators are positive and significant. The pattern of effects indicates that, net of the core model, income inequality is higher in the 1973-81 period than it is in the 1967-72 period, and higher still in the 1982-92 period. This pattern of period indicators confirms that an inequality upswing was a general feature (on average) of the industrial countries over the period covered by our data.

\section{Three Dimensions of Globalization}

In models $3-5$ we investigate aspects of globalization that have been implicated in the upswing in inequality. As the results of model 2 indicate that the Kuznetsian process of declining inequality with development among societies at high levels of development continues to define the inequality experience of the advanced industrial societies into the contemporary period, we proceed by first asking whether the predicted relationships are in evidence, controlling for the core model.

In model 3, we introduce direct investment in the inequality model. The expectation is that DI outflow/labor force (log base 10) will have a positive effect on income inequality. Direct investment outflow is expected to generate inequality because it contributes to deindustrialization, weakens the bargaining position of labor, and affects the distribution of income between capital and labor and the demand for unskilled labor. The results

\footnotetext{
${ }^{25}$ As noted above, we also allow for the possibility that the dispersion of education has come to play an even more important role in recent years (Nielsen and Alderson 1997) - a possibility that we are unable to assess given data limitations.
} 
of model 3 indicate that DI outflow/labor force does indeed have a significant positive effect on income inequality. One interpretation of this finding might be that DI outflow causes deindustrialization, which in turn increases inequality. In another model (not shown), we investigated this possibility by introducing manufacturing's share of employment into the model. While controlling for the share of manufacturing in total employment does attenuate the effect of DI outflow/labor force $(b=1.706$ vs. 2.341), DI outflow continues to have a significant positive effect on inequality. This is consistent with the interpretation offered above that suggests DI may affect income inequality through more than one causal pathway.

In model 4, we address another important aspect of the argument regarding globalization and the contemporary inequality experience of the industrial countries. We introduce southern import penetration/GDP (log base 10) into the core inequality model to test Wood's (1994) argument that trade-induced shifts in the demand for skilled versus unskilled labor have been a major cause of the inequality upswing. Wood proposes that the increasing flow of manufactured goods from South to North over the past two-three decades has affected inequality by depressing the demand for unskilled labor. Model 4 tests the straightforward prediction that southern import penetration will be positively related to inequality. We find that southern imports do have a significant positive effect on inequality. ${ }^{26}$

Wood suggests that the depressed demand for unskilled labor, attributed to the rising volume of trade from the South, has expressed itself differently in different countries. Where institutional resistance to increasing inequality is weak, this demand shift has generated a growing disparity in the wages of the skilled and unskilled. Where institutional resistance to wider wage differentials is strong, increased competition from low-skill nations has expressed itself in rising unemployment. We address the idea that unemployment and inequality can be viewed as trade-offs in the contemporary period in an additional model (not shown) in which we control for the unemployment rate. Wood's argument implies that the effect of southern import penetration will be even larger once the tradeoff is incorporated into the model. We find that the southern import penetration coefficient is not affected by the addition of a control for unemployment and that unemployment is not significantly related to inequality. This result lends further support to critics of the trade-off ar-

\footnotetext{
${ }^{26}$ The number of cases in model 4 falls to 184 because of missing data on the import penetration measure. Specifically, the necessary trade data were missing for the years 1973 and 1975 for New Zealand and 1969 for Australia.
} 
American Journal of Sociology

gument (e.g., Glyn and Salverda 2000; Schmitt and Mishel 2000; see also Bertola and Ichino 1995; Blank 1997).

Model 5 introduces the net migration rate into the core model. If the population that makes up the most recent wave of immigrants to the OECD countries is characterized by low average skills and high skills variance, one would expect to observe a positive relationship between inequality and net migration (Borjas 1994, 2000; Borjas, Freeman, and Katz 1992). As in earlier waves of globalization (Chase-Dunn, Kawano, and Brewer 2000), we expect rich, people-importing countries to experience rising inequality and poor, people-exporting countries to experience declining inequality (Hatton and Williamson 1998, chap. 11). The results presented in model 5 do not bear out this prediction. However, looking ahead to models 11-13, we find that when other variables associated with the U-turn on inequality are controlled, a significant positive effect of net migration emerges.

\section{Institutional Factors}

The results presented thus far suggest (1) that there is a modest tendency for the most developed societies to experience an upturn in inequality beyond a certain level of development, (2) that the Kuznetsian process of declining inequality with development (among societies at high levels of development) continues to define the inequality experience of the advanced industrial societies, (3) that globalization (i.e., the upswings in direct investment, southern import penetration, and immigration) affects inequality independent of factors associated with long-term economic development. In models $6-8$, we turn to investigate a range of institutional factors that may mediate pressures for growing inequality, whether associated with postindustrial development or with globalization.

A number of authors (e.g., Freeman 1993; ILO 1996) have attributed a good part of the inequality upswing to the declining unionization, or "deunionization," that many of the advanced industrial countries have experienced in recent years. Given that unions tend to flatten the distribution of earnings among workers and to reduce the wage differential between blue- and white-collar workers, we predict that the "working class disorganization" (Western 1995) that most advanced industrial countries have experienced in recent years has made an important contribution to the upswing in household income inequality. In model 6, we find that union density has a significant negative effect on income inequality, consistent with the deunionization argument.

In strongly corporatist contexts in which bargaining is national in scope and wage guidelines are centrally fixed, one would expect to observe a flatter distribution of earnings, a smaller blue-collar/white-collar wage 
differential and, ultimately, lower household income inequality. As noted above, such wage-setting coordination can also be achieved outside the context of classic tripartite corporatism; high degrees of coordination can be achieved through the harmonization of industry bargaining by central union confederations or by employer organizations. Recent decades have witnessed a notable erosion of this sort of centralized bargaining in the OECD countries (Western 1995). Thus, to the degree that wage-setting coordination flattens the distribution of earnings, one would expect to observe an upswing in the level of inequality. We test this hypothesis in model 7 . We find that the degree of wage-setting coordination is negatively related to income inequality. This result is consistent with a literature that links wage-setting institutions to a range of economic outcomes (e.g., Kenworthy 2001a; Traxler and Kittel 2000; Flanagan 1999; Soskice 1990).

Where workers find it relatively easy to opt out of work while maintaining an acceptable standard of living, they may be unwilling to accept low-wage jobs. Consequently, pressures for wider wage differentials-whether owing to postindustrial development or to globalization-will necessarily express themselves in a fashion other than rising inequality. Thus we expect to observe a negative relationship between the degree to which the welfare state decommodifies labor and overall income inequality. Model 8 tests this prediction. As one can note, the results indicate that decommodification does indeed have a negative effect on income inequality. In this light, we can make sense of cases such as Sweden, where inequality has more or less remained in check, and Finland, where it has declined. In both countries, the welfare state has, over the period under consideration, increasingly worked to decommodify labor.

Other Factors of Inequality

Model 9 introduces the female labor force participation rate into the core inequality model. Thurow (1987) identifies the upswing in female labor force participation as one of the major causes of rising inequality. Due to women's lower average earnings and to assortative mating, the full-scale entrance of women into the labor force over the past few decades is argued by Thurow to have inflated the bottom of the earnings distribution and to have increased the disparity in income between high- and low-income households. The results of model 9 lend support to this account. Female labor force participation is found to have a significant positive effect on inequality among households. While consistent with Thurow's hypothesis, this finding is open to alternative interpretations. For instance, data limitations preclude us from controlling for changes in household structure. Perhaps the effect of female labor force participation has been confounded 


\section{American Journal of Sociology}

by its association with the growth of female-headed households-a factor that has previously been shown to have played a major role in the inequality upswing in the United States (Levy and Michel 1991; Green, Ryscavage, and Welniak 1991; Nielsen and Alderson 1997). ${ }^{27}$

The link between the upswing in inequality and deindustrialization is assessed in model 10. The shift in employment from manufacturing to services in the course of deindustrialization involves the movement of a fraction of the labor force from a sector typified internally by a relatively high average wage and a relatively flat distribution of income (manufacturing) to a sector typified by a lower average wage and a far wider range of statuses and incomes (services). For these reasons, one would expect to observe an inverse relationship between inequality and the share of manufacturing in total employment. The results of model 10 are consistent with this expectation; the \%labor force in manufacturing has a significant negative effect on household income inequality.

\section{Synthetic Models}

Model 11 introduces the three dimensions of globalization into the core model simultaneously. As noted above, with controls for DI outflow and southern import penetration, the coefficient of the net migration rate becomes positive and significant. Controlling for other aspects of globalization reduces the size of the DI coefficient and increases the size of the southern import penetration coefficient. As regards the core model, one can note that secondary school enrollments continue to have a significant negative effect on inequality. Neither sector dualism nor the natural rate of increase are significant and, surprisingly, \%labor force in agriculture has a significant positive effect on inequality, contrary to expectations. ${ }^{28}$ The positive effect is unexpected because in the Kuznetsian model of dualism, when the measure of sector dualism is included in the model, the coefficient of labor force in agriculture represents the pure effect of inequality within the agricultural sector on overall inequality (Nielsen

\footnotetext{
${ }^{27}$ The finding that female labor force participation has a positive effect on household income inequality also contrasts strikingly with Nielsen and Alderson's (1997) finding that this variable has a negative effect on family income inequality across U.S. counties in 1980 and 1990. This raises the question of whether the GEE assumption that slopes are homogeneous across countries is violated in this instance. Ancillary analyses revealed that the results for female labor force participation are the same when the analysis is performed for the United States alone. We speculate that these divergent findings are attributable to the different units (i.e., households vs. families) employed in the calculation of the Gini coefficient of inequality.

${ }^{28}$ As noted above, the use of a one-tailed test is not strictly justified in this case since the a priori hypothesis specified a negative coefficient. However, the positive coefficient of \%labor force in agriculture is significant using a two-tailed test also.
} 
1994). Since inequality within agriculture is assumed to be less than in the "modern" industrial and services sector, a negative effect of \%labor force in agriculture on income inequality is expected. The positive effect of this variable found in models 11-13 (and in similar models estimated from data on U.S. counties; see Nielsen and Alderson 1997) suggests that Kuznets's dualism model, while important for developing societies, tends to become less relevant for advanced industrial societies in which the agricultural sector has dwindled and sector dualism (which reflects average income differences between agriculture and other sectors) has become a small component of overall inequality. ${ }^{29}$ For such societies, the very meaning of the variable \%labor force in agriculture likely changes to become a measure of agrarian traditionalism rather than a component of the dualism model. The association of this variable with the strength of the traditional agrarian social structure in these societies likely explains the large positive effect on inequality.

The results of models 3-5 and 11 support the existence of a link between various aspects of globalization and the upswing in inequality experienced by a number of the advanced industrial societies in recent decades. Does the link hold net of other factors that have been implicated in the U-turn on inequality? Model 12 introduces the three institutional variables. As one can note, the pattern of results is consistent with that observed in Model 11. Direct investment, southern import penetration, and net migration continue to have significant positive effects on inequality. Likewise, union density, wage setting coordination, and decommodification have effects of roughly similar magnitude to that observed in the individual equations (i.e., models 6-8). Finally, it is important to note that, in this context, the period indicators are no longer significant. This indicates that the variables assembled in model 12 (and model 13) account for consistent period effects associated with inequality.

Finally, in model 13, we introduce female labor force participation and manufacturing's share of employment into the equation. In this context, female labor force participation remains marginally significant, but \%labor force in manufacturing does not appear to have an effect on inequality, net of the other variables in the model. The institutional variables have effects of similar magnitude to that observed in model 12. Interestingly, while the size of the coefficient of the net migration rate grows, the introduction of the two final variables in the model reduces the size of the

${ }^{29}$ The difference between the OECD countries and the less-developed countries in which the expected negative relationship has been observed (e.g., Nielsen and Alderson 1995; Alderson and Nielsen 1999) is of course substantial. Agriculture's share of employment in the World Bank's "low" and "middle income" countries averaged 63\% in 1980 (World Bank 1997), while it averaged just $8 \%$ in the 16 OECD countries under study. 
American Journal of Sociology

DI and southern import penetration coefficients. Given that direct investment and southern imports have both been linked to deindustrialization (Wood 1994; Alderson 1999), these results are not entirely surprising. We interpret them as indicating that \%labor force in manufacturing, as an "internal" variable, partially mediates the effects of direct investment and trade.

\section{CONCLUSIONS}

The upswing in inequality in the OECD countries has spawned a large academic and popular literature. Among the more intriguing (and controversial) explanations for the U-turn on inequality is the idea that growing capital flows, trade, and migration - particularly between "dissimilar" countries-have led to "lost jobs," weakened the bargaining position of labor, and otherwise affected the distribution of income between capital and labor and between the skilled and unskilled. While much of the literature on international trade and investment has tended to downplay the distributional consequences of such factors (e.g., OECD 1994; Krugman and Lawrence 1993), the findings presented in this article establish empirically that direct investment and North-South trade have played a role in the determination of income inequality in the contemporary period. Our results likewise suggest a role for immigration. Utilizing a data set that incorporates information on most of the advanced industrial societies over the period of the inequality upswing, we find clear support for arguments linking globalization and the great U-turn. An additional clue to the role of globalization is that the effects of the two period indicators tracing the inequality upturn disappear or are substantially attenuated when the globalization variables are included in the model.

Direct investment outflow/labor force is found to have a positive effect on income inequality net of the core inequality model and of other factors that have been invoked to account for the recent U-turn on inequality. The finding of a positive association between income inequality and direct investment is consistent with a number of arguments that have recently been advanced regarding the distributional consequences of direct investment. The results lend support to arguments that propose that direct investment affects income inequality by (1) accelerating deindustrialization, (2) weakening the bargaining position of labor, and (3) altering the distribution of income between labor to capital and the demand for unskilled labor. North-South trade, as southern import penetration/GDP, is also found to have a positive effect on income inequality. This finding supports Wood's (1994) view that trade-induced shifts in the demand for skilled versus unskilled labor have been a major cause of the inequality 
upswing. Specifically, the results are consistent with Wood's characterization of the upswing in southern manufactured imports as widening skill differentials in wages. Finally, the finding that the net migration rate has a positive effect on inequality is consistent with the argument of Borjas (1994, 2000), among others, who suggests that the composition of the population of recent immigrants to the OECD countries is such that immigration (1) reduces the returns to unskilled labor (low average skill) and (2) increases skill heterogeneity within the labor force in general (high skill variance).

The analysis also establishes empirically that the recent inequality experience of the OECD countries is associated with (1) the conclusion of the labor force shift from agriculture to the nonagricultural sectors (that generates between-sector inequality-sector dualism - that contributes to overall inequality), (2) the conclusion of the demographic transition (that generates an inverted- $U$ trajectory of inequality as the rate of population growth rises and falls over the course of development), (3) the continuing spread of education with development (that generates a monotonic trend toward declining inequality over the course of development), (4) deunionization (that loosens constraints on wage variation among blue-collar workers and results in widening wage differentials among blue- and whitecollar workers), (5) the decline of wage-setting coordination (that also loosens institutional constraints on wider wage differentials), (6) variation in the degree to which welfare states decommodify labor (and thus reduce incentives to take low wage jobs), (7) the growth of female labor force participation (that generates rising inequality due to women's lower average earnings and assortative mating), and (8) deindustrialization (that generates rising inequality as a consequence of the lower average wage and greater variance in wages in the service sector).

Given that the explanatory variables are rendered in different scales, it is difficult to make any judgment about the substantive significance of the variables of interest (i.e., their relative impact on inequality outcomes) based on the regression coefficients alone. As our research addresses a range of contentious issues with policy implications, it is important to address the question of the relative importance of the various factors implicated in the recent inequality experience of the OECD countries. We do so by calculating four different transformations of regression coefficients for variables that were found to be statistically significant (at better than the 0.10 level, one-tailed test) in model 13. These transformed coefficients are presented in table 6 . In table 6 , the variables have been reordered in descending order of absolute size of the ordinary standardized regression coefficients shown in column 1 . The standardized regression coefficient is the change in the dependent variable $\mathrm{Y}$ associated with an increase in $\mathrm{X}$ of one standard deviation, expressed in standard deviation 
American Journal of Sociology

TABLE 6

Measures of Relative Importance of Variables Statistically Significant in MODEL 13

\begin{tabular}{|c|c|c|c|c|}
\hline Variable & $\begin{array}{l}\text { Standardized } \\
\text { Coefficient* }\end{array}$ & $\begin{array}{l}\text { Semistandardized } \\
\text { Coefficient }^{\dagger}\end{array}$ & $\begin{array}{l}\text { Maximum } \\
\text { Impact }^{*}\end{array}$ & $\begin{array}{l}\text { Maximum } \\
\text { Longitudinal } \\
\text { Impact }^{\S}\end{array}$ \\
\hline \%labor force in agriculture $\ldots$ & .880 & 3.568 & 14.718 & 3.523 \\
\hline Union density $\ldots \ldots \ldots \ldots \ldots$ & -.440 & -1.785 & -6.936 & -.919 \\
\hline Decommodification ............ & -.202 & -.820 & -2.944 & -.480 \\
\hline Southern import penetration/ & & & & \\
\hline GDP $\ldots \ldots \ldots \ldots \ldots \ldots$ & .159 & .645 & 3.158 & 1.374 \\
\hline DI outflow/labor force $\ldots \ldots \ldots$ & .125 & .508 & 2.604 & 1.141 \\
\hline Wage setting coordination .... & -.107 & -.435 & -1.088 & -.510 \\
\hline Secondary school enrollment & -106 & -430 & -2640 & -871 \\
\hline Net migration rate $\ldots \ldots \ldots \ldots$ & $\begin{array}{r}-.100 \\
.099\end{array}$ & $\begin{array}{r}-.430 \\
.401\end{array}$ & $\begin{array}{r}-2.640 \\
2.430\end{array}$ & .835 \\
\hline $\begin{array}{l}\text { Female labor force participa- } \\
\text { tion }\end{array}$ & .064 & .260 & 2.719 & .861 \\
\hline
\end{tabular}

* Unstandardized regression coefficient multiplied by the sample standard deviation of the independent variable $\mathrm{X}$ and divided by the standard deviation of the dependent variable $\mathrm{Y}$. Represents the change in $\mathrm{Y}$ associated with an increase of one standard deviation in $\mathrm{X}$, in standard deviation units of $\mathrm{Y}$.

${ }^{\dagger}$ Unstandardized regression coefficient multiplied by the sample standard deviation of the independent variable $\mathrm{X}$. Represents the change in $\mathrm{Y}$ associated with an increase of one standard deviation in $\mathrm{X}$, in original units of $\mathrm{Y}$.

* Unstandardized regression coefficient multiplied by the maximum range (maximum minus minimum) of $\mathrm{X}$ in the sample. Represents the maximum possible impact of $\mathrm{X}$ on $\mathrm{Y}$ across countries and over time.

${ }^{8}$ Unstandardized regression coefficient multiplied by the average within-country range in $\mathrm{X}$. Represents the maximum longitudinal (over time) impact of $\mathrm{X}$ on $\mathrm{Y}$ within a typical country.

units of Y. What we call the semistandardized coefficient in column 2 of table 6 is closely related to the standardized coefficient. The semistandardized coefficient expresses the change in $\mathrm{Y}$ in the original units of $\mathrm{Y}$ rather than in standard deviation units. Both the standardized and semistandardized coefficients imply the same ordering of the variables.

The table shows that the strongest effect on inequality corresponds to \%labor force in agriculture. Increasing \%labor force in agriculture by one (sample) standard deviation is associated with an increase in inequality of 0.88 standard deviation or, alternatively, 3.568 Gini points. This is a strong positive effect, discussed earlier as anomalous with respect to the Kuznetsian model of sector dualism (which predicts a negative effect), that we interpret as reflecting the continuation of a negative relationship between inequality and development on the descending segment of the Kuznets curve. The next two most important factors are institutional: union density and decommodification. Thus the nature of the labor market (measured by union density) and a measure associated with the success of the social-democratic program (decommodification) appear as principal explanatory factors of the combined variation in income inequality across 
countries and over time. Next come two globalization factors: southern import penetration and DI outflow. Increasing southern import penetration by one standard deviation increases inequality by 0.159 standard deviation (or 0.645 Gini points). ${ }^{30}$ For DI outflow, the corresponding change is 0.125 standard deviation (or 0.508 Gini points). The rest of the variables, in descending order of relative impact, are wage-setting coordination, secondary school enrollment, net migration, and female labor force participation.

While standardized and semistandardized coefficients allow us to compare independent variables according to the relative strength of their effects on inequality, one would also like to have an idea of the maximum impact of a given variable on inequality, given the range of values of that variable in the data set. To do this, table 6 , column 3 , shows the "maximum impact" coefficient calculated by multiplying the regression coefficient by the maximum range of the independent variable in the data. The maximum impact is expressed in Gini percentage points. We note that \%labor force in agriculture is still the strongest factor, with an impressive 14.718 Gini points. The next strongest factor is still union density (-6.936). But now southern import penetration has moved up to become the third most influential independent variable, with a coefficient of -2.944 . The rest of the variables have fairly homogeneous coefficients in the range of 2-3 Gini points, except for wage-setting coordination, which is less potent according to the maximum impact measure.

The maximum range of $\mathrm{X}$ used to derive the maximum impact coefficient is calculated over both countries and time points, and therefore any single country is unlikely to experience such a large change in $\mathrm{X}$ during the period of time under consideration. To provide a better measure of how much a given independent variable may have affected inequality within the history of a single country, we calculated a coefficient of maximum longitudinal impact. This is the regression coefficient multiplied by the average within-country range of $\mathrm{X}$. Thus the coefficient reflects how much change in inequality could have taken place over time in a single country given the typical range of variation in the independent variable within a country. In other words, it is a measure of the extent to which a variable can explain the inequality upturn within a single country (net of any cross-country comparisons). Viewed in this way, the various independent variables fall into a very different ordering. While \%labor force in agriculture is still dominant with 3.523 Gini points, southern import

${ }^{30}$ This indicates a far more modest role for southern import penetration in income inequality than that suggested by Wood (1994), consistent with the research of a number of trade economists (Baldwin and Cain 1997; Borjas, Freeman, and Katz 1992r; Cline 1997; Krugman 1995; Lawrence and Slaughter 1993). 
American Journal of Sociology

penetration (1.374) and DI outflow (1.141) now appear in second and third position with respect to maximum longitudinal impact. This suggests that these two aspects of globalization, while less potent than institutional factors such as union density and decommodification in explaining crosscountry variation in inequality, are more important factors in explaining changes in the inequality history of a given country.

Of the advanced industrial societies in our data set, 10 have experienced rising inequality, or declining then rising inequality, over the 1967-92 period. What are the mechanisms behind this trend? Our empirical results, and particularly the presentation in table 6 , suggest that the answer may be different in a cross-national and in a longitudinal context. On the one hand, if one wants to address the predominantly cross-national comparative issue of which countries have had more or less inequality in their income distribution during the last third of the 20th century, one would look for factors that have both large effects on inequality and that vary substantially in the cross-national dimension. The \%labor force in agriculture, and institutional factors such as union density and decommodification, emerge as prime candidates to explain these cross-country differences. On the other hand, if one wants to explain the trajectory of inequality over time that characterized a given country over this period of time, one would look for variables that have a large longitudinal impact. Thus, while \%labor force in agriculture is still a major factor of the inequality trend in individual countries, globalization trends come to the fore as major explanatory factors. Thus for countries that experienced an inequality upturn during the period, the upward inequality trend may be attributable in substantial part to aspects of globalization we have distinguished, primarily North-South trade and DI outflow, and to a lesser extent immigration.

Our finding of a substantial contribution of globalization trends to trajectories of rising inequality in many advanced industrial countries in the last third of the 20th century should be placed in a broader historical context. While many observers are struck by the unique features of the contemporary period, it is certainly not the first time in world history that the globalization of the economic sphere has affected inequality within societies. It has been argued, for example, that the 1870-1913 period was in many ways similar to the contemporary period investigated in this study. Then, too, globalization in the form of growing international trade and mass-migration from Europe to the New World caused inequality to rise in the rich, people-importing countries of the New World and fall in the (at the time) poor, people-exporting countries of Southern Europe and Scandinavia (Hatton and Williamson 1998, chap. 11). How far will the contemporary trend of rising inequality go? First, as Hatton and Williamson (1998) soberly point out, the globalization trend that began in the 
Income Inequality Trends

late 19th century was reversed after World War I into a general pattern of isolationism marked by rising trade barriers and immigration restrictions. It is at least conceivable that the world of today might experience a similar reversal. Second, in the period between the two world wars, the globalization-inequality relationship was reversed, so that the poorer countries were now experiencing sharply rising inequality. It is also conceivable, even if the world economy continues to become more "global," that the relationship of inequality with globalization will change again and the inequality upswing in advanced industrial societies will level off. To assess such possibilities, further work needs to be done in explicating the mechanisms of income stratification in advanced industrial societies that generate observed levels of income inequality. 


\section{APPENDIX}

Inequality over Time, 16 OECD Countries
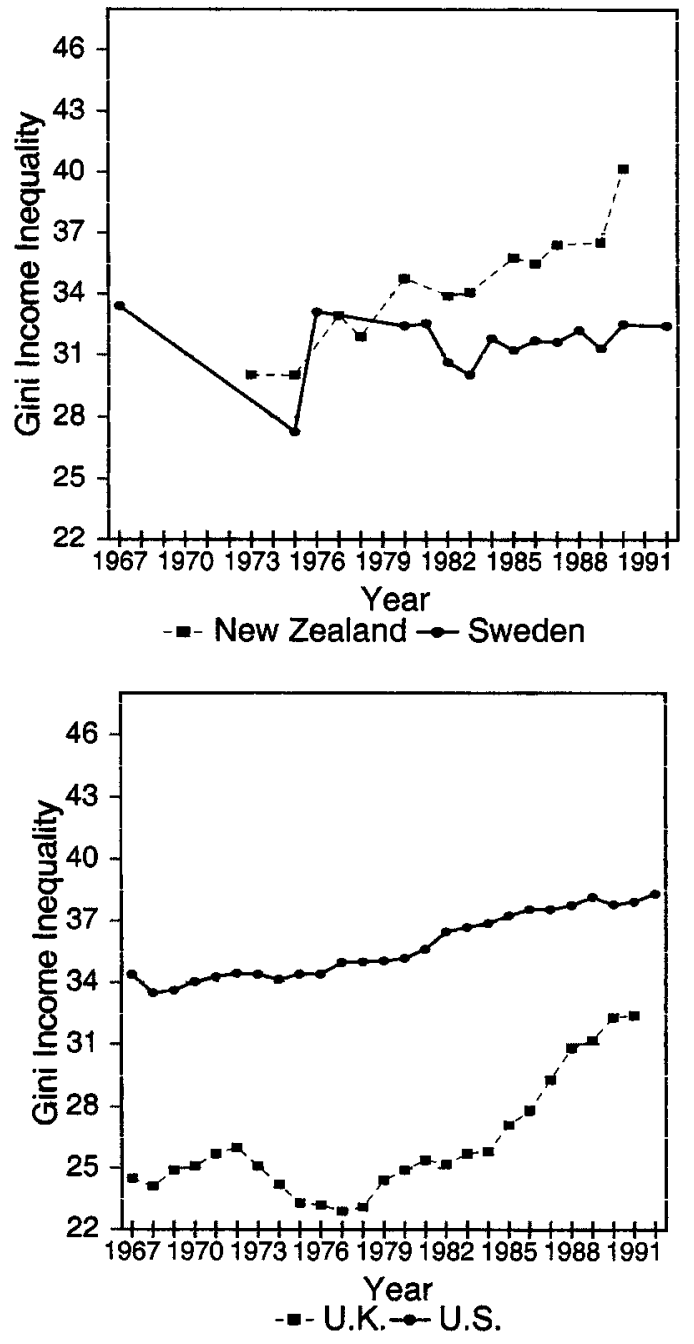

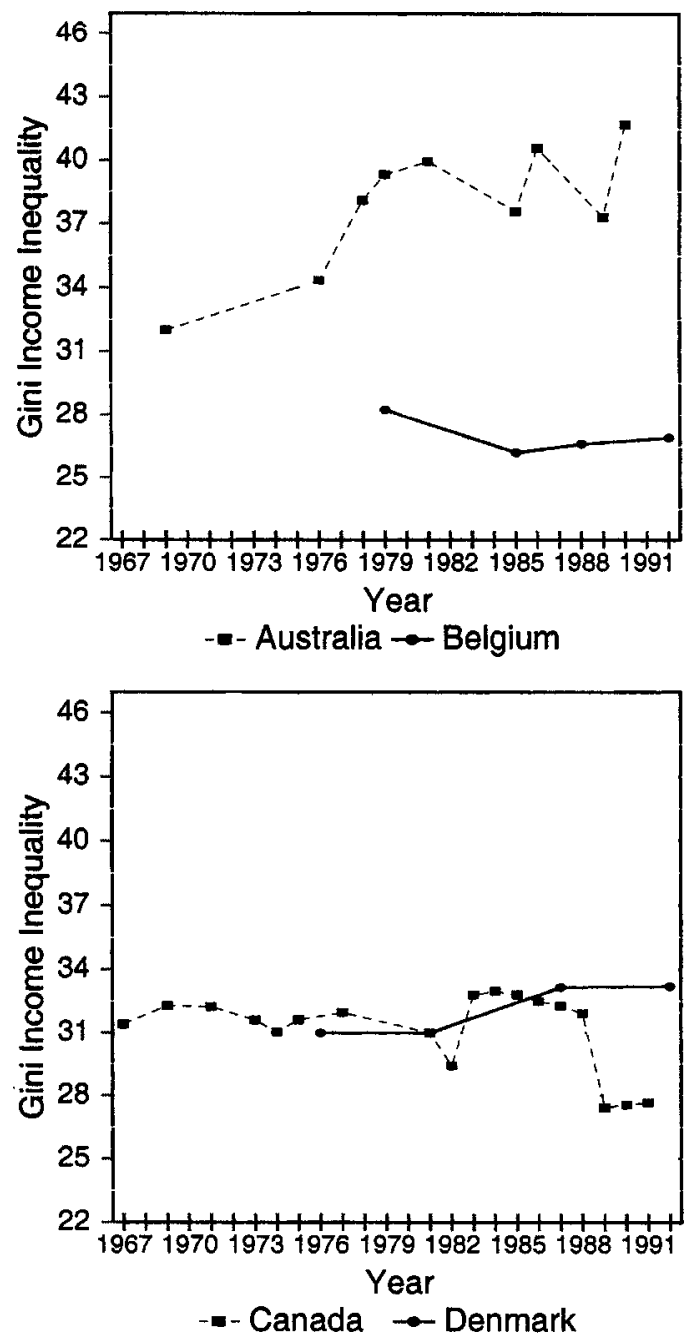

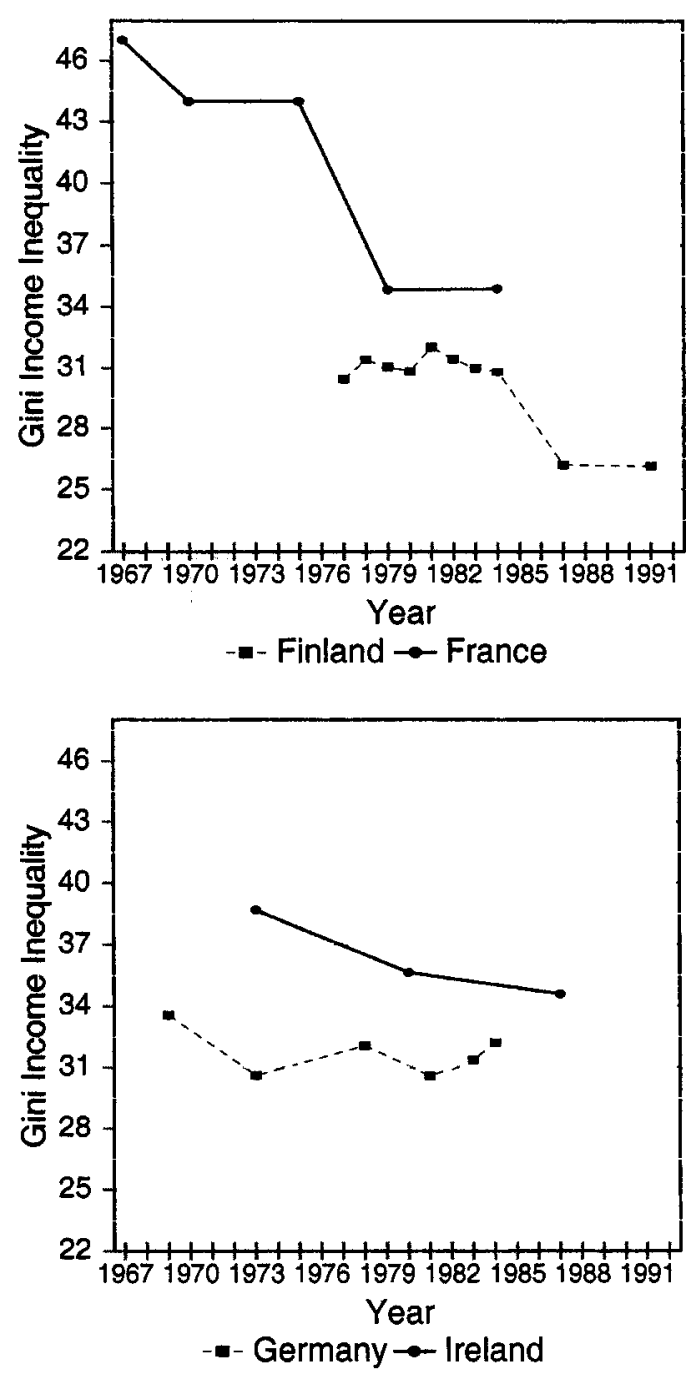

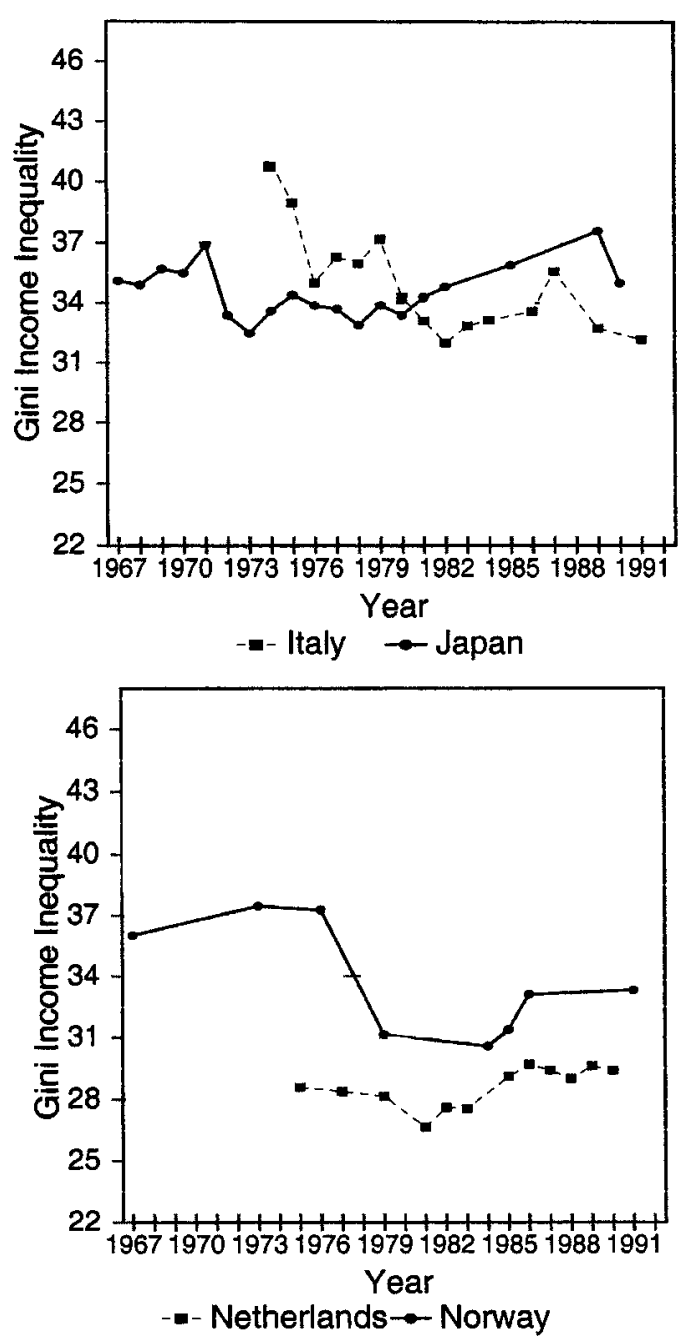

FIG. A1.-Recent trends in income inequality 


\section{American Journal of Sociology}

\section{REFERENCES}

Alderson, Arthur S. 1997. "Globalization, Deindustrialization, and the Great U-Turn: The Growth of Direct Investment in 18 OECD Countries, 1967-1990." Ph.D. thesis. University of North Carolina at Chapel Hill, Department of Sociology.

—. 1999. "Explaining Deindustrialization: Globalization, Failure, or Success?" American Sociological Review 64:701-21.

Alderson, Arthur S., and François Nielsen. 1999. "Income Inequality, Development, and Dependence: A Reconsideration." American Sociological Review 64:606-31.

Atkinson, Anthony B., and Andrea Brandolini. 2001. "Promise and Pitfalls in the Use of 'Secondary' Data-Sets: Income Inequality in OECD Countries as a Case Study." Journal of Economic Literature 39:771-99.

Bhagwati, Jagdish. 1994. "Free Trade: Old and New Challenges." Economic Journal 104:231-46.

Bain, George S., and Robert Price. 1980. Profiles of Union Growth: A Comparative Statistical Portrait of Eight Countries. Oxford: Blackwell.

Baldwin, Robert E., and Glenn G. Cain. 1997. "Shifts in Relative U.S. Wages: The Role of Trade, Technology, and Factor Endowments." Working Paper no. 5934. Washington, D.C.: National Bureau of Economic Research.

Beck, Nathaniel, and Jonathan N. Katz. 1995. "What to Do (and Not to Do) with Time-Series Cross-Section Data." American Political Science Review 89:634-47.

Belsley, David A., Edwin Kuh, and Roy E. Welsch. 1980. Regression Diagnostics: Identifying Influential Data and Sources of Collinearity. New York: Wiley.

Bertola, Giuseppe, and Andrea Ichino. 1995. "Wage Inequality and Unemployment: United States versus Europe" Pp. 13-54 in NBER Macroeconomics Annual 1995, edited by Bernanke Ben S. and Julio J. Rotemberg. Cambridge, Mass.: MIT Press.

Blank, Rebecca M. 1997. "Is There a Trade-off between Unemployment and Inequality? No Easy Answers: Labor Market Problems in the United States versus Europe." Jerome Levy Economics Institute of Bard College Public Policy Brief no. 33.

BLS (U.S. Bureau of Labor Statistics). 1993. "International Comparisons of Manufacturing Productivity and Unit Labor Cost Trends, 1993." Washington, D.C.: BLS.

Bluestone, Barry, and Bennett Harrison. 1982. The Deindustrialization of America. New York: Basic Books.

Bollen, Kenneth A., and Robert W. Jackman. 1985. "Regression Diagnostics: An Expository Treatment of Outliers and Influential Cases." Sociological Methods and Research 13:510-42.

Borjas, George J. 1994. "The Economics of Immigration." Journal of Economic Literature 32:1667-717.

, ed. 2000. Issues in the Economics of Immigration. Chicago: University of Chicago Press.

Borjas, George J., Richard B. Freeman, and Lawrence F. Katz. 1992. "On the Labor Market Impacts of Immigration and Trade." Pp. 213-44 in Immigration and the Work Force: Economic Consequences for the United States and Source Areas, edited by George J. Borjas and Richard B. Freeman. Chicago: University of Chicago Press.

Bornschier, Volker, and Christopher Chase-Dunn. 1985. Transnational Corporations and Underdevelopment. New York: Praeger.

Bornschier, Volker, Christopher Chase-Dunn, and Richard Rubinson. 1978. "CrossNational Evidence of the Effects of Foreign Investment and Aid on Economic Growth and Inequality: A Survey of Findings and a Reanalysis." American Journal of Sociology 84:651-83.

Buckley, Peter J., and Peter Enderwick. 1985. The Industrial Relations Practice of Foreign-Owned Firms in Britain. London: Macmillan. 
Burtless, Gary. 1995. "International Trade and the Rise in Earnings Inequality.” Journal of Economic Literature 33:800-816.

Cameron, David R. 1984. "Social Democracy, Corporatism, Labor Quiescence, and the Representation of Economic Interest in Advanced Capitalist Society.” Pp. 143-78 in Order and Conflict in Contemporary Capitalism, edited by John H. Goldthorpe. Oxford: Clarendon Press.

Cancian, Maria, Sheldon Danziger, and Peter Gottschalk. 1993. "Working Wives and Family Income Inequality among Married Couples." Pp. 195-221 in Uneven Tides: Rising Inequality in America, edited by Sheldon Danziger and Peter Gottschalk. New York: Russell Sage Foundation.

Caves, Richard E. 1982. Multinational Enterprise and Economic Analysis. Cambridge: Cambridge University Press.

Chase-Dunn, Christopher, Yukio Kawano, and Benjamin D. Brewer. 2000. "Trade Globalization since 1795: Waves of Integration in the World-System." American Sociological Review 65:77-95.

Cleveland, William S. 1994. The Elements of Graphing Data, rev. ed. Summit, N.J.: Hobart Press.

Cline, William R. 1997. Trade and Income Distribution. Washington, D.C.: Institute for International Economics.

Cowling, Keith, and Roger Sugden. 1987. Transnational Monopoly Capitalism. New York: St. Martin's.

Crenshaw, Edward, and Ansari Ameen. 1994. "The Distribution of Income across National Populations: Testing Multiple Paradigms." Social Science Research 23: $1-22$.

Danziger, Sheldon, and Peter Gottschalk. 1993. Uneven Tides: Rising Inequality in America. New York: Russell Sage Foundation.

Deininger, Klaus, and Lyn Squire. 1996. "A New Data Set Measuring Income Inequality." World Bank Economic Review 10:565-91.

Dixon, William J., and Terry Boswell. 1996. "Dependency, Disarticulation, and Denominator Effects: Another Look at Foreign Capital Penetration.” American Journal of Sociology 102:543-62.

Drummond, Douglas J., and A. Ronald Gallant. 1979. "TSCSREG: A SAS Procedure for the Analysis of Time Series Cross-Section Data." SAS Technical Report (S-106). Cary, N.C.: SAS Institute.

Enderwick, Peter. 1985. Multinational Business and Labour. New York: St. Martin's Press.

European Industrial Relations Review. Various issues. European Industrial Relations Review.

Esping-Andersen, Gøsta. 1990. The Three Worlds of Welfare Capitalism. Princeton, N.J.: Princeton University Press.

Evans, Peter, and Michael Timberlake. 1980. "Dependence, Inequality, and the Growth of the Tertiary: A Comparative Analysis of Less Developed Countries." American Sociological Review 45:531-52.

Firebaugh, Glenn. 1992. "Growth Effects of Foreign and Domestic Investment." American Journal of Sociology 98:105-30.

1996. "Does Foreign Capital Harm Poor Nations? New Estimates Based on Dixon and Boswell's Measure of Capital Penetration." American Journal of Sociology 102:563-75.

Flanagan, Robert J. 1999. "Macroeconomic Performance and Collective Bargaining: An International Perspective." Journal of Economic Literature 37:1150-75.

Freeman, Richard. 1993. "How Much Has Deunionisation Contributed to the Rise in Male Earnings Inequality?" Pp. 133-63 in Uneven Tides: Rising Inequality in America, edited by Sheldon Danziger and Peter Gottschalk. New York: Russell Sage Foundation. 


\section{American Journal of Sociology}

Freeman, Richard B., and Lawrence F. Katz. 1995. Differences and Changes in Wage Structures. Chicago: University of Chicago Press.

Gagliani, Giorgio. 1987. "Income Inequality and Economic Development." Annual Review of Sociology 13:313-34.

Glyn, Andrew, and Wiemer Salverda. 2000. "Does Wage Flexibility Really Create Jobs?" Challenge 43:32-43.

Gottschalk, Peter, and Sheldon Danziger. 1984. "Macroeconomic Conditions, Income Transfers and Poverty." Pp. 185-215 in The Social Contract Revisited, edited by D. Lee Bawden. Washington, D.C.: Urban Institute Press.

Gottschalk, Peter, Björn Gustafsson, and Edward Palmer. 1997. The Changing Distribution of Economic Well-being: International Perspectives. Cambridge: Cambridge University Press.

Gottschalk, Peter, and Timothy M. Smeeding. 1997. "Cross National Comparisons of Earnings and Income Inequality." Journal of Economic Literature 35:633-87.

Green, Gordon, John Coder, and Paul Ryscavage. 1992. "International Comparisons of Earnings Inequality for Men in the 1980s." Review of Income and Wealth 38: $1-15$.

Green, Gordon, Paul Ryscavage, and Edward Welniak. 1991. "Factors Affecting Growing Income Inequality: A Decomposition." Paper presented at the Western Economic Association International conference, Seattle, July.

Greene, William H. 1993. Econometric Analysis, 2d ed. Englewood Cliffs, N.J.: Prentice Hall.

Gustafsson, Björn, and Mats Johansson. 1999. "In Search of Smoking Guns: What Makes Income Inequality Vary over Time in Different Countries." American Sociological Review 64:585-605.

Hadi, Ali S. 1992. "Identifying Multiple Outliers in Multivariate Data." Journal of the Royal Statistical Society. Ser. B, 54:761-71.

. 1994. "A Modification of a Method for the Detection of Outliers in Multivariate Samples." Journal of the Royal Statistical Society. Ser. B, 56:393-96.

Harrison, Bennett, and Barry Bluestone. 1988. The Great U-Turn. New York: Basic Books.

Hatton, Timothy J., and Jeffrey G. Williamson. 1998. The Age of Mass Migration: Causes and Economic Impact. New York: Oxford University Press.

Hicks, Alexander, and Lane Kenworthy. 1998. "Cooperation and Political Economic Performance in Affluent Democratic Capitalism." American Journal of Sociology 103:1631-72.

Hsiao, Cheng. 1986. Analysis of Panel Data. New York: Cambridge University Press.

Hufbauer, Gary C., and F. Michael Adler. 1976. Overseas Manufacturing Investment and the Balance of Payments. New York: Arno.

Huizinga, Harry. 1990. "Unions, Taxes, and the Structure of Multinational Enterprises." Economics Letters 34:73-75.

Ietto-Gillies, Grazia. 1992. International Production: Trends, Theories, Effects. Cambridge: Polity Press.

ILO (International Labour Organization). 1996. World Employment 1996/97. Geneva: ILO.

IMF (International Monetary Fund). 1977. Balance of Payments Manual, 4th ed. Washington, D.C.: IMF.

- 1987. Balance of Payments Statistics Yearbook. Washington, D.C.: IMF. 1994. Balance of Payments Statistics Yearbook. Washington, D.C.: IMF.

Iversen, Torben. 1999. Contested Economic Institutions. New York: Cambridge University Press.

Jacobs, David. 1985. "Unequal Organizations of Unequal Attainments? An Empirical Comparison of Sectoral and Individualistic Explanations for Aggregate Inequality." American Sociological Review 50:166-80. 
Income Inequality Trends

Karoly, Lynn A. 1993. "The Trend in Inequality among Families, Individuals, and Workers in the United States: A Twenty-five Year Perspective." Pp. 19-97 in Uneven Tides: Rising Inequality in America, edited by Sheldon Danziger and Peter Gottschall. New York: Russell Sage Foundation.

Kenworthy, Lane. 2001a. "Corporatism and Unemployment in the 1980s and 1990s." Unpublished manuscript. Emory University, Department of Sociology.

. 2001b. "Wage Setting Coordination Scores." Unpublished manuscript. Emory University, Department of Sociology.

Koopmans, Lambert H. 1987. Introduction to Contemporary Statistical Methods. Boston, Mass.: Duxbury Press.

Krugman, Paul. 1995. "Growing World Trade: Causes and Consequences." Brookings Papers on Economic Activity 1:327-62.

Krugman, Paul, and Robert Z. Lawrence. 1993. "Trade, Jobs, and Wages." Working Paper no. 4478. Washington, D.C.: National Bureau of Economic Research.

Kuznets, Simon. 1953. Shares of Upper Income Groups in Income and Savings. New York: National Bureau of Economic Research.

. 1955. "Economic Growth and Income Inequality." American Economic Review 45:1-28.

Lawrence, Robert Z., and Matthew J. Slaughter. 1993. "International Trade and American Wages in the 1980s: Giant Sucking Sound or Small Hickup?" Brookings Papers on Economic Activity 2:161-226.

Lecaillon, Jacques, Felix Paukert, Christian Morrisson, and Dimitri Germidis. 1984. Income Distribution and Economic Development: An Analytical Survey. Geneva: International Labour Office.

Lee, Eddy. 1996. "Globalization and Employment: Is Anxiety Justified?" International Labour Review 135:485-97.

Lehmbruch, Gerhard. 1984. "Concentration and the Structure of Corporatist: Networks." Pp. 60-80 in Order and Conflict in Contemporary Capitalism, edited by John H. Goldthorpe. Oxford: Clarendon Press.

Levy, Frank. 1987. Dollars and Dreams. New York: Russell Sage Foundation.

Levy, Frank, and Richard C. Michel. 1991. The Economic Future of American Families: Income and Wealth Trends. Washington, D.C.: Urban Institute Press.

Levy, Frank, and Richard J. Murnane. 1992. "U.S. Earnings Levels and Earnings Inequality: A Review of Recent Trends and Proposed Explanations." Journal of Economic Literature 30:1333-81.

Liang, Kung-Yee, and Scott L. Zeger. 1986. "Longitudinal Data Analysis Using Generalized Linear Models." Biometrika 73:13-22.

Lindert, Peter H. 2000. "Three Centuries of Inequality in Britain and America." Pp. 167-216 in Handbook of Income Distribution, vol. 1. Edited by Anthony B. Atkinson and François Bourguignon. Amsterdam: Elsevier Science.

Lindert, Peter H., and Jeffrey G. Williamson. 1985. "Growth, Equality, and History." Explorations in Economic History 22:341-77.

Lorence, Jon, and Joel Nelson. 1993. "Industrial Restructuring and Metropolitan Earnings Inequality, 1970-1980." Research in Social Stratification and Mobility 12: $145-84$.

Marks, Gary. 1986. "Neocorporatism and Incomes Policy in Western Europe and North America." Comparative Politics 18:253-77.

Messerlin, Patrick A. 1995. "The Impact of Trade and Capital Movements on Labor: Evidence on the French Case." OECD Economic Studies 24:89-124.

Morris, Martina, and Bruce Western. 1999. "Inequality in Earnings at the Close of the 20th Century." Annual Review of Sociology 25:623-57.

Neter, John, Michael H. Kutner, Christopher J. Nachtsheim, and William Wasserman. 1996. Applied Linear Statistical Models. Chicago: Irwin. 


\section{American Journal of Sociology}

Nielsen, François. 1994. "Income Inequality and Industrial Development: Dualism Revisited." American Sociological Review 59:654-77.

Nielsen, François, and Arthur S. Alderson. 1995. "Income Inequality, Development, and Dualism: Results from an Unbalanced Cross-National Panel." American Sociological Review 60:674-701.

- 1997. "The Kuznets Curve and the Great U-Turn: Patterns of Income Inequality in United States Counties, 1970-1990." American Sociological Review 62: $12-33$.

- 2001. "Trends in Income Inequality in the United States." Pp. 355-85 in Sourcebook on Labor Markets: Evolving Structures and Processes, edited by Ivar Berg and Arne L. Kalleberg. New York: Plenum.

Nygård, Fredrik, and Arne Sandström. 1981. Measuring Income Inequality. Stockholm: Almquist \& Wiskell.

OECD (Organisation for Economic Co-operation and Development). 1984. Foreign Trade by Commodities. Paris: OECD.

- 1989. Labour Force Statistics, 1967-1987. Paris: OECD.

- 1992. Foreign Trade by Commodities. Paris: OECD.

- 1994. The OECD Jobs Study: Facts, Analysis, Strategies. Paris: OECD.

- 1995a. Income Distribution in OECD Countries: Evidence from the Luxembourg Income Study. Paris: OECD.

. 1995b. Labour Force Statistics, 1973-1993. Paris: OECD.

. Various years. National Accounts. Paris: OECD.

Preston, Valerie, and Sara McLafferty. 1993. "Income Disparities and Employment and Occupational Changes in New York." Regional Studies 27:223-35.

Raffalovich, Lawrence. 1993. "Structural Sources of Change in Earnings Inequality." Research in Social Stratification and Mobility 12:113-44.

Ram, Rati. 1997. "Level of Economic Development and Income Inequality: Evidence from the Postwar Developed World." Southern Economic Journal 64:565-83.

Ryscavage, Paul, Gordon Green, and Edward Welniak. 1992. "The Impact of Demographic, Social, and Economic Change on the Distribution of Income." U.S. Bureau of the Census, Ser. P60, no. 183. Washington, D.C.: U.S. Bureau of the Census.

Schmitt, John, and Lawrence Mishel. 2000. "The United States Is Not Ahead in Everything that Matters." Challenge 41:39-59.

Schmitter, Philippe C. 1974. "Still the Century of Corporatism?" Review of Politics 85:93-94.

Scott, Allen J., and Michael Storper. 1986. Production, Work, Territory: The Geographical Anatomy of Industrial Capitalism. Boston: Allen \& Unwin.

Soskice, D. 1990. "Wage Determination: The Changing Role of Institutions in Advanced Industrialized Societies." Oxford Review of Economic Policy 6:36-61.

StataCorp. 1997. Stata Statistical Software: Release 5.0. College Station, Tex.: Stata Corporation.

Summers, Robert, and Alan Heston. 1991. "The Penn World Table (Mark 5): An Expanded Set of International Comparisons, 1950-1988." Quarterly Journal of Economics 106:327-68.

Thurow, Lester C. 1987. "A Surge in Inequality." Scientific American 256:30-37.

Traxler, Franz, and Bernhard Kittel. 2000. "The Bargaining System and Performance: A Comparison of 18 OECD Countries." Comparative Political Studies 33:1154-90.

United Nations. 1989. World Population at the Turn of the Century. New York: United Nations.

U.S. Department of Health and Human Services. Various years. Social Security Programs throughout the World. Washington, D.C.: U.S. Department of Health and Human Services. 


\section{Income Inequality Trends}

Väyrynen, Raimo. 1997. Global Transformation: Economics, Politics, and Culture. Helsinki: Finnish National Fund for Research and Development.

Visser, Jelle. 1989. European Trade Unions in Figures. Boston: Kluwer.

1996. "Unionization Trends Revisited." Unpublished paper. Amsterdam: Centre for Research on European Societies and Industrial Relations.

Wallerstein, Michael. 1999. "Wage-Setting Institutions and Pay Inequality in Advanced Industrial Societies.” American Journal of Political Science 43:649-80.

Western, Bruce. 1995. "A Comparative Study of Working-Class Disorganization: Union Decline in Eighteen Advanced Capitalist Countries." American Sociological Review 60:179-201.

Wilkinson, Leland. 1990a. SYGRAPH: The System for Graphics. Evanston, Ill.: SYSTAT, Inc

1990b. SYSTAT: The System for Statistics. Evanston, Ill.: SYSTAT.

Williamson, Jeffrey G. 1991. Inequality, Poverty, and History. Cambridge, Mass.: Basil Blackwell.

Wood, Adrian. 1994. North-South Trade, Employment, and Inequality. Oxford: Oxford University Press.

World Bank. 1997. World Development Indicators [CD-ROM]. Washington, D.C.: World Bank.
Various years. World Tables. Baltimore: Johns Hopkins University Press 